(Aus dem physiologischen Institut zu Breslau.)

\title{
Neue Versuche über die Aufsaugung im Dünndarm.
}

Von

\section{R. Heidenhain.}

\section{§ 1. Gesichtspunkte der Untersuchung.}

Absonderung und Aufsaugung spielen bei der Stoffbewegung im Thierkörper eine wesentliche Rolle. Bei beiden Vorgängen treten wässrige Lösungen organischer und anorganischer Substanzen durch thierische Membranen hindureh. Die Natur der Triebkräfte, welche diese Massenbewegung veranlassen, genauer zu bestimmen, hat die Physiologie sich redliche Mühe gegeben.

Um die Zeit, als unsre Wissenschaft durch die Einfubrung strenger physikalischer Untersuchungsmethoden von dem Banne der Naturphilosophie befreit wurde, suchte man im Anschlusse an die Erfahrungen der Physik über Filtration und Osmose den Sitz jener Triebkräfte ausserhalb der Häute, durch welche die Fortführung derFlüssigkeiten geschieht: Unterschiede des hydrostatischen Druckes auf beiden Seiten der Membranen (Filtration) oder der chemischen Zusammensetzung (Diffusion) schienen gentigend zur Erklärung der Stoffwanderung, und damit eine zureichende Dentung der Erscheinung gegeben.

Aber die berühmten Untersuchungen C. Ludwig's über die Absonderung des Speichels zeigten an dem Beispiele der betreffenden Drüsen, dass die Triebkraft für den Wasserstrom, welcher bei Reizung der Drüsennerven aus dem Blute bezw. der Lymphe in die Drtisenräume sich ergiesst, nicht in dem in der Flüssigkeitsquelle herrschenden Drucke gegeben sei, dass vielmehr von den Wandungen der Drüsenbläschen eine Triebkraft entwickelt werde, weit mächtiger als der Druck des Capillarblutes und unabhängig von diesem, welche den Strömungsvorgang herstellt. Der Sitz der Triebkraft lag also nicht ausserhalb der Membran, welche von der Fltissigkeit durchsetzt wird, sondern innerbalb derselben,

E. Pflüger, Archiv f. Physiologie. Bd. 56. 
Seit vielen Jahren mit den Vorgängen der Resorption und Secretion beschäftigt, babe ich gesehen, dass die Speicheldrüsen nicht ein in ibrer Art vereinzelter Mechanismus sind. Es hat sich gezeigt, dass Aehnliches für alle Drüsen gilt. Am längstens wurde die Filtrationstheorie für die Niere festgehalten. In meiner Arbeit über die Absonderungsvorgänge ${ }^{1)}$ habe ich eine Reihe von Griunden zusammengestellt, welche es nothwendig erscheinen lassen, auch hier die Membran (der Glomeruli, wie gewisser Harncanälchen) für die Absonderung verantwortlich zu machen, eine Auffassung, die zunächst von vielen Seiten beanstandet wurde, aber in der neueren Entwicklung der physikalischen Chemie die Mittel fand, ihr gutes Recht an der Hand messender Versuche geltend zu machen ${ }^{2}$ ).

Vor Kurzem habe ich in einer experimentellen Untersuchung über die Bildung der Lymphe auf eine Reibe von Erscheinungen aufmerksam: gemacht, die auch für diesen scheinbar einfachsten Fall des Durchtrittes von Flüssigkeit durch Membranen (der Capillaren) sich nicht deuten lassen, wenn man nur auf die ausserhalb der Membranen wirkenden Kräfte der Filtration und Diffusion zurïckgeht. Anch hier wird man durch die Thatsachen zu dem Schlusse gedrängt, dass die Capillarmembranen einen mehr als bloss passiven Antheil an der Lymphbildung nehmen. Wiederum hat meine Auffassung zwar von vielen Seiten Zustimmung, aber anch hier und da Widerspruch gefunden. Ich beabsichtige an dieser Stelle keineswegs, auf die Erörterung der einschlägigen Fragen einzugehen ${ }^{3}$ ). Aber wiederholen möchte ich mit Betonung, dass es sich auch bei den Fragen nach den Ursachen der Lymphbildung zunächst um gar nichts weiter bandelt, als um die Ermittlung, ob die Ursachen derselben lediglich ausserhalb der Capillarmembranen oder nicht vielmehr, wenn auch nicht ausschliesslich, so doch zum guten Theil innerhalb derselben zu suchen seien. Die Feststellung des Ursprungsortes also der Triebkräfte ist es allein, worauf es bei dem hentigen Entwicklungsstandpunkt der physiologischen Erkenntniss in den Fragen der Secretion und

1) Hermann's Handbuch V.

2) Dreser: Ueber Diurese und ihre Beeinflussung durch pharmakologische Mittel. Archiv f. experimentelle Pathologie und Pharmacologie. Bd. 29. S. 314.

3) Vgl. die folgende Abhandlung. 
Resorption ankommt; erst wenn dieser Punkt zweifellos festgestellt ist, wird es sich um die Aufklärung über die Natur der Triebkräfte handeln.

Ich setze eigentlich voraus, dass manchem Leser diese ganze Erörterung überflüssig erscheinen wird. Allein sie wird für mich nothwendig gegenuiber einer Verdunkelung der Fragestellung, welche mir hier und da begegnet. Es ist nicht selten die Rede von einer "vitalistischen" Auffassung in meinen Arbeiten ${ }^{\mathbf{1}}$ ). Gegen diese Darstellung muss ich auf das Entschiedenste Verwahrung einlegen.

Es führt stets zur Verwirrung, wenn Ansdrieke, die in der Wissenschaft ein althergebrachtes Bürgerrecht haben, in einem andern, als dem herkömmlichen Sinne gebraucht werden. Daraus entstehen nur Missverständnisse, die ich für mich nicht aufkommen lassen möchte.

Unter Vitalismus versteht man bekanntlich diejenige Auffassung der physischen Vorgänge im lebenden Organismus, welche annimmt, dass hier Kräfte andrer Ordnung und andrer Natur ihr Wesen treiben, als bei den Processen in der anorganischen Welt. Einer derartigen Annahme stehe ich durchaus ferm. Wenn ich oft von einer "Thätigkeit der lebenden Zelle" gesprochen habe und auch in der folgenden Abhandlung sprechen werde, so verstehe ich unter der ,activen Rolle" der Zelle nichts Anderes, als dass die in der Zelle stattfindenden oder von ihr ausgehenden physikalischen und chemischen Vorgänge eine nachweisbare Veränderung an der Zelle selbst (z. B. amöboide Bewegung am Leucocyten, Verkürzung an der Muskelzelle, Bildung von Secretionsmaterial in der Drüsenzelle) oder in ihrer Umgebung (z. B. Bewegung von Flüssigkeit) hervorrufen. Ich stehe also ganz und voll auf dem Boden rein physikalischer Auffassung.

Aber es ist nöthig anzuerkennen, dass die Physik der Zelle uns fuir heute noch nicht klar liegt und liegen kann, weil wir in ihren unendlich verwickelten anatomischen und chemischen Bau noch wenig Einblicke besitzen. Wir sind deshalb in der übeln Lage, für die Wirkungen der Zelle vorläufig noch Collectivausdrïcke, wie „Lebensthätigkeit" u. dergl. gebrauchen zu müssen, weil die

1) Vgl. z. B. W. Cohnstein, Verhandlungen der physiologischen Gesellschaft zu Berlin. Jahrg. 1893-1894. No. 1. Sitzung vom 28. Juli 1893. S. 8. 
Zerlegung der Gesammtwirkung in ihre einzelnen Componenten heute, kaum ein balbes Jahrhundert nach der Entdeckung der Zelle, noch nicht möglich ist.

Ein Dampfschiff fahre neben einem Holzkahn auf einem Flusse stromabwärts. Ein unbefangener Zuschauer am Ufer, noch unbekannt mit dem Dampfer, würde beim ersten Anblicke ohne Zweifel geneigt sein, die Strömung allein für die Bewegung beider Fahrzeuge verantwortlich $\mathrm{zu}$ machen, bis er die Leistungsfähigkeit beider genauer vergleicht. Beide schwimmen ja in der Ricbtung des Stromes; beide fabren schneller bei starker, langsamer bei schwacher Strömung; die Bewegung beider wird also durch die lebendige Kraft des Wassers beeinflusst. Da sie die ausreichende Ursache für die Bewegung des Holzkahnes ist, könnte sie auch die alleinige Triebkraft für den Dampfer sein. Erst genauere Untersuchung beider Fahrzeuge zeigt, dass das Dampfschiff zu andern Leistungen befähigt ist, als der Holzkahn. Denn jenes kann mit dem Strome schwimmen, schneller als die Wassermasse vorwärts treibt, oder langsamer, oder auch gegen den Strom; der Holzkahn schwimmt im Strome mit dessen eigner Geschwindigkeit. In dem Dampfer sind also besondere Triebkräfte vorhanden, deren Natur und Ursprung genauer erforseht wird, indem man die einzelnen Theile des Schiffes untersucht.

Hätte aber das Dampfschiff mikroskopische Dimensionen, so wïrde eine solche Zerlegung in die einzelnen Theile und die Feststellung ibrer Einzelleistungen zunächst auf unïberwindliche Schwierigkeiten stossen. Der Untersucher würde dabei stehen bleiben müssen, nachzuweisen, dass das Schiff im Strome eine eigne "Thätigkeit" zu entwickeln im Stande ist und nicht bloss von äussern Kräften getrieben wird. Dabei ist durchaus nichts „Mystisches" (von „Zellenmysticismus" ist jetzt oft genug die Rede), sondern das ist einfach naturwissenschaftliche Logik.

Kehren wir zur Secretion und Resorption zurück. Gewiss sind alle Membranen der Blutgefässe, Drïsen u.s.f. geeignet, u n ter passenden Bedingungen Filtration und Diffusion zu gestatten. Wer aber behauptet, dass die Flüssigkeitsbewegung innerhalb des Organismus durch jene Häute hindurch allein Folge von Filtration bez. Osmose sei, und diese Behauptung lediglich damit begründet, dass man an ihnen unter gewissen experimentellen Umständen beiderlei Vorgänge nachweisen kann, hat den Beweis für 
seine Behauptung noch keineswegs erbracht. Er hat vielmehr die Pflicht, darzuthun, erstens, dass im Organismus bei dem normalen Geschehen die Bedingungen für jene Processe in Wirklichkeit gegeben sind, zweitens, dass die thatsächlich im Organismus stattfindende Stoffbewegung durch die hydrostatischen bez. osmotischen Druckkräfte vollständig verständlich wird.

Das letztere trifft aber, so viel ich sehe, in den allermeisten Fällen nicht zu; vielleicht ist es nirgends zutreffend. Die Membranen selbst, d. h. die sie zusammensetzenden Zellen entwickeln Triebkräfte, welche in die Stoffbewegung eingreifen und nicht selten dieselbe so vollkommen beherrschen, dass die äussern Triebkräfte dagegen in den Hintergrund treten.

Es ist nicht schwer, künstliche Scheidewände zu construiren, welche Filtration bez. Diffusion zulassen und gleichzeitig selbstständig die Stoffwanderung beeinflussen. Eine Anzahl von Zinkund Kupferplatten sei zu je zweien mit einer Fläche verlöthet, so dass sie Doppelplatten mit je einer freien Zink- und einer Kupferfläche bilden. Solche Doppelplatten seien in eine poröse Thonplatte fensterartig so versenkt, dass alle Zinkflächen an der einen, alle Kupferflächen an der andern Seite der Thonplatte frei zu Tage liegen.

Wenn eine so armirte Thonplatte in einem ersten Falle als Scheidewand zwischen Salzlösungen verschiedener Zusammensetzung aufgestellt wird, tritt natïrlich durch die Thonstreifen, welche zwischen den Metallplatten liegen, Diffusionsaustausch der beiderseitigen Lösungen ein.

Gleichzeitig aber entwickelt die Scheidewand electrische Triebkräfte, welche Wanderung von Wasser und von fortgeführten Jonen bewirken und deshalb den Stoffaustausch der beiderseitigen Fltissigkeiten wesentlich beeinflussen.

Die innern Triebkräfte der Scheidewand treten rein zu Tage, wenn sie in einem zweiten Falle Lösungen gleicher Zusammensetzung trennt: die Osmose fällt fort, trotzdem wird eine durch jene inneren (electrischen) Triebkräfte bedingte Stoffwanderung eintreten.

Das Verhältniss wird im Wesentlichen dasselbe bleiben, wenn man sich die Metallplatten auf sehr kleine Dimensionen eingeschrumpft denkt, so dass sie nicht mehr ohne Weiteres sichtbar sind; dabei können sie in am so grösserer Zahl in der Thonplatte 
verborgen sein. Wer mit einer solehen scheinbar einfachen Thonplatte Diffusionsversuche anstellt, wird leicht verführt werden können, die Resultate seiner Versuche allein durch osmotische Triebkräfte zu erklären, da ja die Erscheinungen der Osmose im Allgemeinen sich werden nachweisen lassen. Erst die genauere Untersuchung der Stoffbewegung durch die Platte, qualitativ und quantitativ; bei möglichster Abänderung der Bedingungen, wird darauf aufmerksam machen, dass die Osmose allein zur. Deutung der thatsächlichen Stoffbewegung nicht ausreicht, und auf innere Triebkräfte der Scheidewand hinweisen.

Die absondernden und aufsaugenden Membranen des Thierkörpers sind nun Sitz solcher innerer Triebkräfte, ganz unbeschadet der Möglichkeit der Filtration und Diffusion durch dieselben. Dass letztere Vorgänge an ihnen ablaufen $k \ddot{o} n n e n$; beweist nicht; dass sie die einzigen oder auch nur hauptsächlichen Factoren bei der Absonderung bez. Aufsaugung sind. Die lebenden Zellen entwickeln eigne Triebkräfte, welche jene äussern, je nach Umständen, unterstützen oder überwinden können und oft genug von einer Mächtigkeit sind, dass die vorhandenen hydrostatischen oder osmotischen Druckkräfte dagegen verschwinden. Die Feststellung dieser Thatsache hat Nichts mit "Vitalismus" oder "Zellenmysticismus" zu thun, wenn auch die Natur jener innern Triebkräfte vorläufig so wenig definirt werden kann, wie es bei dem oben erwähnten mikroskopischen Dampfschiffe möglich sein würde.

Die folgenden Untersuchungen iuber den Vorgang der Aufsaugung im Dünndarm haben den Zweck, an einem concreten Beispiele klarer, als es bisher möglich war, die Richtigkeit der oben entwiekelten Auffassung darzulegen.

Die Resorption der wässrigen Darmflüssigkeiten ${ }^{1}$ ) galt lange Zeit als einfacher Diffusionsvorgang. Nur durch dünne Häute (Epithelschicht und Capillarmembranen) von dem Blute getrennt, sollten sie nach denselben Gesetzen, welche für den Diffusionsvorgang durch todte Scheidewände gelten, in das Blut hineindiffundiren und die Bedingung für den osmotischen Vorgang durch

1) Die Fettresorption wird in der vorliegenden Abhandlung nicht berücksichtigt. 
die fortwährende Ernenerung des Blutes innerhalb der Capillaren dauernd aufrecht erhalten bleiben.

Gegen diese gewiss ansprechende physikalische Auffassung sind oft Bedenken erhoben worden, zuerst wohl von Ho p peS ey le $\mathrm{r}^{1}$ ), weleher die Triebkraft für den Uebergang des Darminhaltes in die circulirenden Säfte nicht in der chemischen Verschiedenheit der Flïssigkeiten suchte, sondern in das lebende Epithel der Darmwand verlegte. Seine Anschaung fand vielfache Unterstützung, u. A. in einer Reihe ans meinem Institut hervorgegangener Arbeiten ${ }^{2}$ ). Doch scheinen die in diesen Untersuchungen ermittelten Thatsachen nicht durchschlagend genug gewesen zu sein, um die Ansicht zu erschüttern, dass bei der Darmresorption die Hauptrolle der Diffusion zukomme, obschon ja hier und da zugegeben wird, dass nicht alle Erscheinungen der Resorption aus den Diffusionsgesetzen ableitbar seien. Die Unsicherheit der Bèurtheilung spricht sich in den nenesten Lehrbuichern der Physiologie auf das Deutlichste aus.

So lese ich bei L. Herman ${ }^{3}$ ): „Die Kräfte, welche die „Aufsaugung bewirken, sind noch unbekannt. Vieles spricht dafür, ,dass für Wasser und äeht gelöste Substanzen die „Diffusion (Endosmose) e ine Rolle spielt, da die Blutgefäse ,von einer relativ concentrirten Flüssigkeit durchströmt werden ,und diese nur durch dïnne poröse Gebilde von der ganz anders „zusammengesetzten Flüssigkeit im Darmlumen getrennt ist".... Und nach Anführung einiger Thatsachen, welehe der Osmoselehre widersprechen: „Es scheinen also selbst bei den einfachen "Resorptionsprocessen unverständliche Eigenschaften "der Epithelzellen eine Rolle zu spielen."

1) Hoppe-Seyler, Physiologische Chemie. Berlin 1881. S. 348.

2) G. Leubuscher: Studien ïber Resorption seitens des Darmcanales. Jena 1885 .

Gumilewski: Ueber Resorption im Dünndarm. Pflüg er's Archiv Bd. 39.

F. Röhmann: Ceber Secretion und Resorption im Dünndarm. Ebendas. Bd. 41 .

R. Heidenhain: Beiträge zur Histologie und Physiologie der Dünndarmschleimhaut. Ebendas. Supplementheft zu Bd. 43.

3) L. Hermann, Lehrbuch der Physiologie. 10. Aufl. 1892. S. 202. 
Ferner bei Gad und Heymans ${ }^{1}$ ): „Das Wasser, die Salz„und Zuckerlösungen gehen unverändert hauptsächlich in die Blut„capillaren über; die osmotischen Kräfte erklären diesen "Uebergang grösstentheils."

Endlich sagt J. $M \mathrm{u} \mathrm{n}^{2}$ ): „Zwischen dem Inhalt der Blat„und Lymphgefässe einerseiț und dem Darminhalte andrerseits „kann durch das Schleimbautepithel und die dünnen Gefässwände „hindurch nach den Gesetzen der Membrandiffusion ein Stoffaus„tausch stattfinden. Auf diesem Wege könnten Wasser, Salze und ,Zucker aus dem Darmrohr in das in der Wand strömende Blut "und in die Lymphe ibertreten, sobald der Darminhalt an Wasser, "Salzen resp. Zucker reicher ist, als das Blut und die Lymphe."

Diese Anführungen genügen, um die herrschende Unsicherheit bezüglich der Theorie der Darmresorption zu kennzeichnen. Eine erneute Untersuchung bedarf keiner weiteren Rechtfertigung.

\section{§. Methode der Untersuchung.}

Aus der heutigen Entwicklung der Lehre von der Osmose lassen sich einige, für die folgende Untersuchung wichtige Sätze. ableiten, welche voranzustellen zweckmässig erscheint:

1. Sind wässrige Lösungen von gleicher endosmotischer Spannung durch eine Diffusionsmembran getrennt, so findet eine Volumsänderung der Flüssigkeiten nicht statt.

2. Befinden sich auf den beiden Seiten der Membran Lösungen von ungleicher Spannung, so geht Wasser von der Seite der geringeren Spannung nach der andern Seite iber.

3. Die endosmotische Spannung eines Lösungsgemenges ist gleich der Summe der Partiarspannungen der einzelnen gelösten Bestandtheile.

4. Befinden sich auf beiden Seiten der Membran Lösungen von gleicher Gesammtspannung, aber ungleicher Partiarspannung der gelösten Bestandtheile, so geht jeder Bestandtheil der Lösungsgemenge von der Seite, auf welcher er die höhere Partiarspannung

1) Gad und Heymans: Kurzes Lehrbuch der Physiologie. Berlin 1892. S. 427 .

2) J. Munk: Physiologie des Menschen und der Säugethiere. 3. Aufl. Berlin 1891. S. 194. 
besitzt, nach der andern Seite über, bis die beiderseitigen Partiarspannungen sich ausgeglichen haben; eine Aenderung der beiderseitigen Wasservolumina findet nicht statt.

Beruht die Darmresorption auf Diffusion, so müssen die bei derselben auftretenden Erscheinungen allen obigen Sätzen genügen. Die Erfahrung zeigt, dass diese Forderung nicht erfullt wird.

Die Durchführung meines Planes, nach den obigen Grundsätzen die Probe auf das Exempel anzustellen, setzt die Bestimmung der endosmotischen Spannung einerseits der Blutflüssigkeit, andrerseits der im Darm zur Resorption gelangenden Flüssigkeiten voraus. Dieselbe geschah mittelst des Be ckma n n'schen Gefrierapparates ${ }^{1}$ ), welchen auf dem Gebiete der thierischen Physiologie ztierst Dreser ${ }^{2}$ ) für ähnliche Zwecke verwandte. Die Gefriermethode ist in den Händen der Physiker noch keineswegs zu dem erwünschten Grade der Vollkommenheit gebracht, was ich hervorhebe, weil ich in den physiologischen Arbeiten, die sich ihrer bedienen ${ }^{3}$ ), ihre Mängel nicht erwähnt finde, obschon die Physik sich uber dieselben fort und fort beschwert und sie zu beseitigen trachtet ${ }^{4}$ ). Von den unten citirten Forschern hat namentlich L o o m is hervorgehoben, dass das Resultat der Gefrierpunktsbestimmungen von einer Reibe von Proceduren abhängt, welche der Willkür des Experimentators anheim gestellt sind; eigne Erfahrungen, gesammelt im Laufe eines Jahres, haben mich zum

1) E. Beckmann, Ueber die Methode der Moleculargewichtsbestimmung durch Gefrierpunktserniedrigung. Ostwald's Zeitschr. für physikalische Chemie. Bd. II. S. 638.

2) Dreser: Ueber Diurese und ihre Beeinflussung durch pharmacologische Mittel. Arch. f. exp. Pathol. u. Pharmacol. Bd. 29.

3) Grijns: Die Temperatur des in die Niere einströmenden Blutes und des aus ihr abströmenden Harnes. Arch. f. Anat. u. Physiol., physiol. Abth. 1893.

Hamburger: osmotische Spannkraft seröser Flüssigkeiten. Physiol. Centralbl. 24. Febr. 1894.

4) Vgl. die im letzten Jahre erschienenen Arbeiten von Raoult (Bestimmung des Gefrierpunktes wässriger Lösungen von grosser Verdünnung. Ztschr. f. physikal. Chemie. Bd. 9. 1892. S. 343). Ferner H. C. Jones: Ueber den Gefrierpunkt sehr verdünnter Lösungen. Ebendas. Bd. XI. 110. - E. H. Loomis: Ueber ein exacteres Verfahren bei den Bestimmungen von Gefrierpunktserniedrigungen. Wiedemann's Annalen N. F. Bd. 511894. S. 500. Nachschrift zu dem letzteren Aufsatze von Kohlrausch. 
Theil auf dieselben Punkte aufmerksam gemacht, die Loom is hervorhebt. Namentlich der Grad der Unterkühlung, bevor man das Wasser zum Ausfrieren bringt, die Schnelligkeit oder Langsamkeit des Riihrens, die Temperatur der Gefriermischung haben einen Einfluss, dessen Grösse sich in den Differenzen der Angaben über den Gefrierpunkt gleicher Lösungen bei verschiedenen Experimentatoren kund gibt. Nach einer Zusammenstellung bei L o o m is schwankt der Werth der Gefrierpunktserniedrigung $(\mathcal{A})$ einer 3,3 procentigen Zuckerlösung in den in der Literatur seit 1888 vorliegenden Arbeiten zwischen 0,201 und 0,240, also um 0,039 ; offenbar liegt der Grund in der Verschiedenheit der Handhabung des Gefrierapparates (s. oben).

Meine eignen Resultate sind mit ähnlichen Schwankungen behaftet; meine Versuche erstrecken sich über den Zeitraum eines Jahres, innerhalb dessen ich erst allmählich die Bedeutung der obigen drei Veränderlichen (Unterkühlung, Schnelligkeit des Rubrens, Temperatur des Gefriergemisches) durch die Häufung meiner Erfahrungen kennen lernte. In ein und derselben Versuchsreihe, innerhalb deren ich immer in gleicher Weise verfuhr, sind die Schwankungen geringer (bis höchstens etwa $0,01^{0} \mathrm{C}$ ), als in weiter auseinander liegenden Versuchsreihen, bei denen ich allmählich das Verfahren veränderte. So erhielt ich für eine einprocentige Kochsalzlösung, die ich sehr oft bestimmt habe, in den verschiedenen Reihen Werthe zwischen $0,628-0,640$. Jone s fand fiir eine Chlornatriumlösung von $1,12 \% A=0,658$, woraus sich für $1 \% A=0,587$ berechnet. $\mathrm{R}$ tù d or f gibt 0,600 an, $\mathrm{H}$ a mburg er 0,606 , Dreser 0,613 . Die Schwankungsgrenzen sind also in meinen verschiedenen Reihen gleich 0,012 , in den Reihen andrer Forscher $0,613-0,587=0,026$. Den Grund, weshalb ich etwas höhere absolute Werthe gefunden habe, als sie sonst angegeben werden, bin ich ausser Stande gewesen zu ermitteln. Die Kochsalzlösungen wurden durch Abwägung des Salzes angefertigt und mittelst einer von Herrn Professor $\mathrm{R} \ddot{o} \mathrm{~h} \mathrm{man} \mathrm{n}$ hergestellten Lösung von salpetersaurem Silber durch Titration controlirt.

Als physikalisch sicher kann also die Gefriermethode keineswegs gelten. Glücklicher Weise aber ist sie für die mir vorliegenden Fragen trotzdem vollkommen verwendbar. Denn die Unterschiede der endosmotischen Spannungen, um welche es sich bei den in meinen Versuchen in Frage kommenden Flüssigkeiten 
handelt, sind so ausserordentlich viel grösser, als die Schwankungen bei den Einzelbestimmungen derselben Flüssigkeit, dass über die Anwendbarkeit oder Unanwendbarkeit der im Eingange dieses Paragraphen aufgestellten Sätze auf den Vorgang der Darmresorption mit voller Sicherheit entsehieden werden kann.

Eine besondere Bemerkung habe ich noch über das Thermometer des Beckmann'schen Gefrierapparates zu machen; ich habe dasselbe von Herrn Götze in Leipzig bezogen, der auch für B. selbst arbeitete. Das Thermometer ist für Gefrierpunktsbestimmungen in verschiedenen Lösungsmitteln construirt und deshalb mit einem grossen Quecksilbervorrathe versehen, von welchem für jedes Lösungsmittel nur ein gewisser Theil verwandt wird. Den Uebersehuss nimmt das untere Ende einer cylindrisehen Kammer auf, welche an die oben umgebogene Thermometercapillare angeblasen ist; in das obere Ende derselben dringt bei Zimmertemperatur das Gebrauchsquecksilber ein, um sich bei $0^{0}$ in die Capillare zurückzuziehen. Als ich nun dieses Thermometer einige Wochen gebrancht hatte, stellte es sich herans, dass der Gefrierpunkt des Wassers von Tag zu Tag auf der Scala herunterrückte, bis er gegen das untere Ende derselben gelangt war ${ }^{1}$ ); dann musste die Menge des Gebrauchsquecksilbers, vergrössert werden, um ihn wieder dem obern Scalenende zu nähern. Das Thermometer befand sich stets in verticaler Stellung, sorgfältig geschützt vor E1schütterungen. Die allmähliche Verschiebung konnte kaum einen anderen Grund haben, als dass sich in der Zwischenzeit zwischen je 2 Versuchen sehr geringe Mengen von dem Gebrauchsquecksilber am obern Ende der Kammer ablösten und zu dem Quecksilberiuberschuss am untern Ende der Kammer gelangten. Sowohl um diesem Uebelstande zú entgehen, als auch um über ein Instru-

1) So stand der Gefrierpunkt z. B. am
6. 2. 93 bei 2,920
8. 2. " , 2,850
10. 2 . $" ~ " 2,819$
13. 2. " " 2,665
17. $2 ., " 2,002$
20. 2. " " 1,881
22. 2. " " 1,723
25. 2. $, " 1,680$
27. 2 . " $" 1,487$ u. s. f. 
ment von geringerer Quecksilbermasse, also grösserer Einstellungsgesehwindigkeit zu verfügen, bat ich Herrn Götze um Anfertigung eines Thermometers, welches nur für Gefrierung von wässrigen Lösungen gebraucht werden sollte. Der Nullpunkt liegt bei diesem nahe dem obern Ende der Scala; das Quecksilber; so weit dasselbe bei Zimmertemperatur in der Capillare nicht mehr Platz findet, wird von einer kleinen Ausweitung ihres obern Endes aufgenommen. Die gesammte Quecksilbermasse ist etwa nur halb so gross, als in dem ersten Thermometer. Auch bei diesern Instrumente rückt der Gefrierpunkt des Wassers allmählich abwärts, aber sehr langsam, so dass er sich im Laufe von 9 Monaten nur um ungefähr $0,15^{\circ} \mathrm{C}$. verschoben bat. Das erheblich kleinere Quecksilbergefäss ermöglicht die Bestimmung von $\mathcal{A}$ unter Benutzung einer viel kleineren Flüssigkeits-Menge, als bei dem ersten Thermometer.

Soviel bezüglich der Gefriermethode. Ueber den allgemeinen Gang meiner Versuche ist wenig zu sagen. Alle Beobachtungen wurden an Hunden angestellt, welche 40 Stunden vor dem Versuche ihre letzte Mahlzeit erhalten hatten. Im Zustande tiefer Narcose (durch subcutane Morphium-Injection und zeitweise Einathmung eines Gemenges von Chloroform und Aether zu gleichen Theilen) wurden die Thiere auf dem Rücken liegend aufgebunden, die Bauchhöhle in der linea alba eröffnet und eine passende Darmschlinge hervorgebolt. Es ist erforderlich, bei Vergleichsversuchen an einer Reihe von Thieren stets Schlingen derselben Lage za benutzen. Ich wählte nach einigen Erfahrungen immer das unterste Ende des Dünndarmes, in einer Entfernung von $8-10 \mathrm{~cm}$ vom Dickdarm; nur bei den ersten Versuchen wurden Schlingen in der Mitte des Dünndarmes verwandt. Die Länge der Schlinge wird zweckmässig nicht zu gering genommen; ich wechselte in der Regel zwischen $80-120 \mathrm{~cm}$, gemessen an dem Darm unmittelbar nach seiner Entblössung, indem ich denselben an einem Bindfaden von der betreffenden Länge entlang gleiten liess ${ }^{1}$ ). Die gemessene Schlinge wird dann an beiden Enden abgebunden, beiderseits" eröffnet und durch einen Strom körperwarmer physiologischer Kochsalzlösung gereinigt. Sehr unangenehm ist die bäufige Anwesen-

1) Wenn man dieselbe Schlinge, nachdem sie den Versuchen gedient hat, am todten Thiere misst, hat sie sich in der Regel verlängert, in Folge der Erschlaffung der Musculatur. 
heit von Bandwïrmern, deren Entfernung nicht immer vollständig gelingt. Die Reste der Spülflüssigkeit werden durch sanftes mehrmaliges Ausstreichen entfernt, die auf ihre Resorption zu prüfende Flïssigkeit eingefüllt, die Darmschlinge reponirt und nach Schliessung der Banchwunde bis zum Ablaufe der beabsichtigten Resorptionsdauer sich überlassen. Sodann Hervorholen der Schlinge, vollständige Entleerung der rïckständigen Flïssigkeit und nach Umständen erneute Anfuillung. Ich habe bei vorsichtigem Manipuliren dieselbe Schlinge zu 5-6 auf einander folgenden Versuchen benutzen können; bei Verwendung derselben Resorptionsflüssigkeit gab der letzte Versuch fast genau das gleiche Resultat, wie der erste.

\section{\$ 3. Resorption bei Ausschluss der Diffusion.}

Wenn die Darmresorption auf Diffusion der Darmflïssigkeiten in das Blut beruht, miissen solche Flüssigkeiten von der Resorption ausgeschlossen sein, welche die gleiche endosmotische Spannung haben, wie die Blutflüssigkeit.

Ausgeschlossen muss also in dem Darm des Hundes das Serum seines Blutes sein. Freilich strömt in den Capillaren nicht Serum, sondern Plasma, aber beide haben gleiche endosmotische Spannung, da das bei der Gerinnung ausfallende Fibrin die Spannung nicht beeinflusst. Als ich die jetzt mitzutheilenden Versuche begann, war ich noch nicht im Besitze des Gefrierapparates. Aber ohne allen Zweifel hat das Serum des gleichen Thieres bei gleicher Concentration auch gleiche, oder doch mindestens fast angenähert gleiche Spannung. Die Concentrationsunterschiede sind ja bekanntlich durch Schwankungen des Eiweissgehaltes, nicht der Salze, bedingt, und jener hat auf die endosmotische Spannung nur einen überaus kleinen Einfluss. Nach D res e ${ }^{1}$ ) verringert sich der Werth von $A$ für das Blutserum durch Abscheidung des Eiweiss nur um $0,01-0,02^{\circ} \mathrm{C}$. Wie Nernst ${ }^{2}$ ) nach Sabanajew und Alexander mittheilt, ist für eine 14,5 prozentige Lösung von Eiweiss in Wasser $\Delta=0,020$, für eine 44,5 prozentige Lösung $A=0,060$. Ob diese

1) Dreser: Ueber Diurese u. s. f. Arch. f. exp. Pathol, und Pharmacol. Bd. 29. S. 314. Anm.

2) W. Nerust, Theoretische Chemie. Stuttgart 1893. S. 327. 
geringfiigige Gefrierpunktserniedrigung nicht zum Theil auf anorganische Bestandtheile, die dem Eiweiss beigemischt sind, zu bezieben sei, lässt Nernst mit Recht dahingestellt. Wie dem auch sei, die mitzutheilenden Versuche werden lehren, dass Serum anch bei viel böherer Spannung, als die des strömenden Blutes, im Darme noch leicht zur Resorption gelangt.

$$
\text { Versuch vom 29. 11. 921). }
$$

Bei einem früh 6 Uhr gefütterten Hunde von 10,76 Kilo Gewicht wrurden um 91/2 Uhr in eine Darmschlinge von $48 \mathrm{~cm}$ Länge (Abstand vom Pylorus $30 \mathrm{~cm}$ ) nach sorgfältiger Reinigung $40 \mathrm{ccm}$ Serum eines Tages zuvor getödteten Hundes eingeführt. Um $1 \mathrm{Uhr}$ war die Schlinge vollständig leer.

Das in den Darm gefüllte Serum hatte $6,76 \%$ an festen Theilen, das eigne Serum des Versuchshundes $8,03 \%$. Es blieb also für den Vertheidiger der Diffusionstheorie der Einwand, dass ersteres Serum eine geringere Spannung besessen habe, als letzteres, also die Resorption durch Diffusion erfolgt sei. Diesen Einwurf widerlegt der

$$
\text { Versuch vom 1. } 12.92 .
$$

Hund 4,92 Kilo. Letzte Mahlzeit vor 48 Stunden. Darmschlinge $41 \mathrm{~cm}$ lang. Um $10 \mathrm{Uhr}$ Einfüllung von $36 \mathrm{~cm}$ Serum mit $8,03 \%$ Trockengehalt. Nach $31 / 2$ St. Schlinge leer. Serum des Versuchshundes hat $8,07 \%$.

Dieser Versuch lebrt also, 1. dass die Resorption des Serum auch dann erfolgt, wenn dasselbe den gleichen Procentgehalt hat, wie das des Versuchsthieres ${ }^{2}$ ); 2. dass die Serumresorption im Darme des nüchternen Thieres ebenso vollständig erfolgt, wie in dem des verdauenden.

Ausdrücklich sei hervorgehoben, dass wenn ich hier von Resorption des Serums spreche, die Versuche doch zunächst nur das Verschwinden des Serumwassers beweisen. Für die Entscheidung über die Diffusionstheorie genügt aber die Feststellung dieser Thatsache.

Nun könnte weiterhin der freilich von vornherein kaum haltbar erscheinende Einwand erhoben werden, dass die Gleichheit

1) Bei den ersten Resorptionsversuchen, die ich anstellte, sind noch manche Abweichungen von dem im vorigen Paragraphen mitgetheilten allgemeinen Versuchsplan vorgekommen; den letzteren nahm ich erst im Verlaufe der Arbeit an.

2) Der Unterschied von $0,04 \%$ ist völlig belanglos. 
der Concentration der beiderseitigen Sera noch nicht die Gleichheit ihrer endosmotischen Spannungen verbürge. Der folgende Versuch giebt die Antwort.

$$
\text { Versuch vom 5. } 12.92 .
$$

Serum des vorigen Versuchsthieres wird im Vacuo über Schwefelsäure so weit concentrirt, das sein Procentgehalt auf $11,97 \%$ steigt. Einem Hunde von $10 \mathrm{Kilo}$, dessen Serum einen Procentgehalt von 6,47\% hatte, werden in eine Jejunum-Schlinge $40 \mathrm{~cm}$ jenes eingedickten Serums eingeführt. Nach $31 / 2$ St. sind nur noch $3 \mathrm{ccm}$ einer dicklichen Flüssigkeit von schleimiger Consistenz vorhanden. - Dieser Versuch, wie einige ähnliche (s. unten), beseitigte alle Zweifel; dass das eingeengte Serum eine erheblich höhere Spannung gehabt hat, als das Serum des Versuchsthieres, bedarf keines Wortes. Die Resorption ist unter Umständen erfolgt, welche die Beförderung des Darminhaltes in das Blut hinein durch osmotische Triebkräfte mit absoluter Sicherheit ausschliessen.

Die mitgetheilten Versuche lehren nichts iuber die Geschwindigkeit der Serumresorption, denn die Hunde wurden nach Anfiillung des Darmes mit Serum erst zu einer Zeit getödtet, um welche die Darmschlinge vielleicht, ja höchst wahrscheinlich, schon lange leer war. Es wurden deshalb Versuche mit so kurzer Resorptionsdauer angestellt, dass in der Schlinge noch ein grösserer oder geringerer Antheil der eingeführten Flüssigkeit rückständig war.

Diese Versuche sollen aber noch über einen anderen Punkt Aufschluss geben. Der Vertheidiger der Diffusionstheorie könnte vielleicht den Einwand erheben, das in den Darm gefuillte Serum sei vor seiner Resorption durch Darmsecrete stark verdïnnt worden, sodass seine osmotische Spannung unter die des circulirenden Blutes gesunken sei; damit seien aber die Bedingungen für die Diffusion hergestellt. Die Zahlen der folgenden Tabelle widerlegen diese Deutung: zu keiner Periode der Resorption findet sich im Darme eine Flüssigkeit von geringerer Concentration als die ein-, gefiihrte. 
T a b e ll e F. Resorption von Hundeserum.

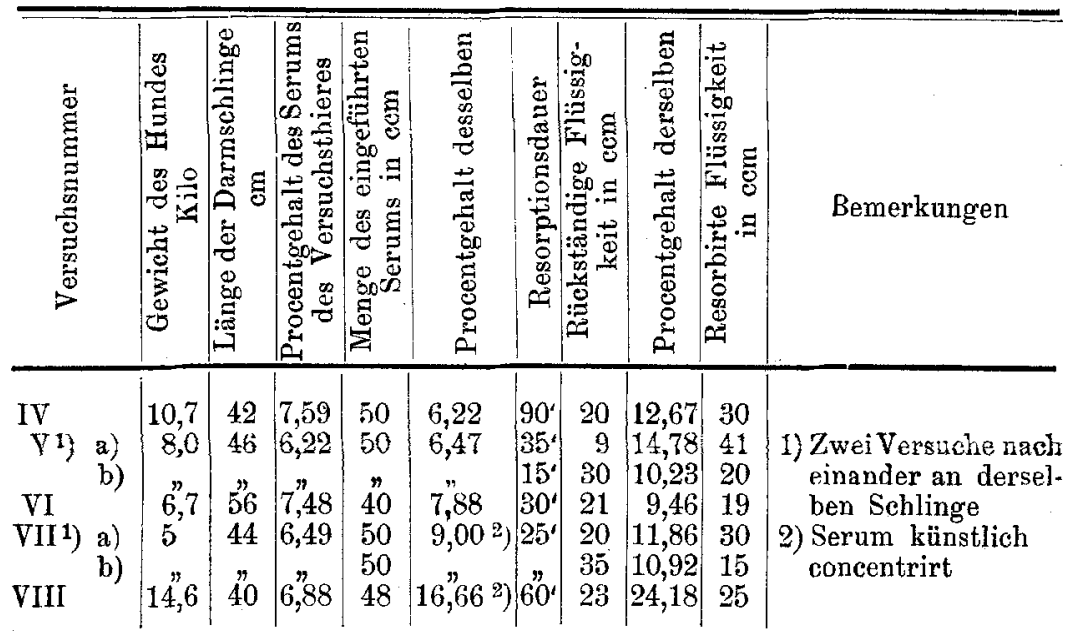

Gleichviel ob in den Darm natürliches oder durch Wasserverdunstung innerhalb der oben angegebenen Grenzen concentrirtes Serum eingeführt wird, niemals findet während der Resorption eine Concentrationsabnahme, sondern immer eine stetig fortschreitende Concentrationszunahme statt. Die Geschwindigkeit der Resorption lässt eine bestimmt ausgesprochene Gesetzlichkeit nicht erkennen; die Individualität des Thieres hat einen unläugbaren Einfluss, der sich auch bei den später mitzutheilenden Resorptionsversuchen in unverkennbarer Weise zeigt.

Zur vollen Einsicht in den Ablauf des Resorptionsvorganges war es nun noch erforderlich festzustellen, worauf die allmählige Concentrirung des in den Darm eingeführten Serums beruht, ob nämlich allein das Wasser desselben verschwindet, oder ob mit ihm die crystalloiden and colloiden Bestandtheile der Flissigkeit den Darm verlassen. Wenn letzteres der Fall war, konnte es, angesichts der Concentrationszunahme, nur mit geringerer Geschwindigkeit geschehen sein, als die Entfernung des Wassers.

Dass die Albuminate des Serums schwer resorbirbar sind, bat bereits vor langer Zeit C. Voit festgestellt. Die Schwierigkeit der Darmwand, colloide Stoffe aufzunehmen, lässt sich sebr sinnfällig zeigen, wenn man in eine Darmschlinge gewässertes Blut einführt. In einem ersten Versuche füllte ich eine Blutlösung von $12,5 \%$ in eine Darmschlinge von $40 \mathrm{~mm}$ Länge, in ejnem 
zweiten Falle in eine Schlinge von $56 \mathrm{~cm}$ Länge eine Lösung von $10,15 \%$ Gehalt. Das eigene Serum des ersten Hundes hatte einen Trockengehalt von $8,81 \%$, das des zweiten einen Trockengehalt von $7,48 \%$. In beiden Fällen war nach $2 \frac{1}{2}$ Stunden die Flüssigkeit aus dem Darm verschwunden, anf die Schleimhaut aber eine dicke breiige rothe Schicht abgelagert, welche nach Ausweis des Mikroscops theils aus Stromaten rother Blutkörperchen, theils aus zahllosen Hämoglobincrystallen bestand. Der Blutfarbstoff war also zum grössten Theile im Darm zurückgeblieben.

Er war hiernach mit Sicherheit vorauszusehen, dass auch die Eiweisssubstanzen des Serums bei seiner Resorption zum guten Theile zurückbleiben würden; die Concentrationszunahme desselben während des Ablaufes der Aufsaugung konnte hierin allein ihren Grund haben. Möglicherweise blieb aber auch ein Theil der Salze zurück. Nur der directe Versuch konnte Aufschluss geben. Bei seiner Anstellung berücksichtigte ich gleichzeitig noch die zweite Frage, ob das resorbirte Serum durch die Blutbahnen oder durch die Chyluswege der Zotten fortgeführt werde.

$$
\text { Versuch IX (22. 2. 93). }
$$

Hund 11,7 Kilo.

Die endosmotische Spannung seines Serums war $A=0,612$. - Einfüh. rung einer Canüle in den ductus thoracicus. Unterbindung des Dünndarmes dicht unterhalb des d. pancreaticus und kurz vor der valv. Bauhini.

Von $9^{\mathrm{h}} 36^{\prime}-10^{\mathrm{h}} 21^{\prime}$ aufgefangen $16 \mathrm{ccm}$ Lymphe, d.h.pro Minute $0,35 \mathrm{ccm}$.

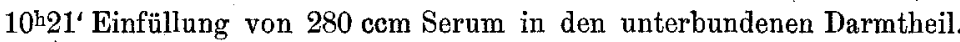
Der benutzte Serum hatte $\boldsymbol{A}=0,583$; dasselbe enthielt $6,80 \%$ Trockensub. stanz, und zwar $5,96 \%$ organische Bestandtheile, $0,84 \%$ Salze. Im Ganzen waren also mit dem Serum eingeführt 16,69 gr organische Substanzen, 2,34 gr Salze.

Von $10^{\mathrm{h}} 21^{\prime}-11^{\mathrm{h}} 11^{\prime}$ aufgefangen $33 \mathrm{ccm}$ Lymphe, d. h. pro $1 \mathrm{Min}$. $0,66 \mathrm{ccm}$. Wäre die Lymphe mit derselben Geschwindigkeit geflossen wie vor der Füllung des Darmes, so würden in der Zeit von 50 Minuten $18 \mathrm{ccm}$ Lymphe entleert worden sein. Die Lymphvermehrung beträgt also 33-18 $=15 \mathrm{~cm}$.

Um 11h11' enthielt der Darm noch 85 cem Flüssigkeit; mit $A=0,577$. Der Werth von $A$ hat sich also nur um $0,583-0,577=0,006$ geändert, eine in die Fehlergrenzen fallende Ziffer. - Die Flüssigkeit hatte 12,86\% an Trockensubstanz, ihr Gehalt war also um $12,86-6,80=6,06 \%$ gestiegen. Der organische Gehalt betrug $11,94 \%$, der Salzgehalt $0,92 \%$; die gefundenen $88 \mathrm{ccm}$ Flüssigkeit enthielten also $10,51 \mathrm{gr}$ organische Substanzen, 0,81 gr Salze. Mithin berechnen sich die resorbirten Mengen in folgender Weise: 


\begin{tabular}{lccc} 
& a) Flüssigkeit & b) organische Substanzen & c) Salze \\
Eingeführt & $280 \mathrm{ccm}$ & $16,69 \mathrm{gr}$ & $2,35 \mathrm{gr}$ \\
Rückständig & $88 \#$ & $10,51 \#$ & 0,81, \\
\cline { 2 - 5 } Resorbirt & $192 \mathrm{ccm}$ & $6,18 \mathrm{gr}$ & $1,54 \mathrm{gr}$
\end{tabular}

Oder in Procenten:

Von dem eingeführten Wasser sind resorbirt $68 \%$

$"$ den $"$ Salzen $" \quad$ " $65 \%$

" " $\quad$ organischen Substanzen $31 \%$

Salz und Wasser sind also in nahezu gleichem Verhältnisse, die organischen Sulustanzen dagegen in weit geringerem Verhältnisse, als die ersteren, resorbirt worden.

\section{Versueh X (27. 2. 93).}

Allgemeine Bedingungen, wie bei dem vorigen Versuche.

Hund 11,6 Kilo. - $A$ seines Serums 0,626.

Lymphe aus dem d. thoracicus von $9 \mathrm{~h} 15^{\prime}-10^{\mathrm{h}} 7^{\prime} 7 \mathrm{ccm}$, d. i. pro $1 \mathrm{Min}$. $0,15 \mathrm{cem}$.

$10^{\mathrm{h}}$ : Einführung von $330 \mathrm{ccm}$ Serum $(A=0,617)$ in den Darm. Procentgehalt desselben 6,31; organische Substanz 5,35\%, Salze 0,96\%; also eingeführt $17,65 \mathrm{gr}$ org. Substanz, 3,17 gr Salze.

12h $2^{\prime}-12^{\prime}: 2 \mathrm{ccm}$ Lymphe, d. i. pro $1 \mathrm{Min} .0,20 \mathrm{ccm}$

$10^{\mathrm{h}} 12^{\prime}-11^{\mathrm{h} 2} \mathrm{2}: 11, \quad ", \quad 1$ " 11,22 "

$12^{\mathrm{h} 2}$ : rückständige Flüssigkeit $190 \mathrm{~cm} ; A=0,600$; Procentgehalt 9,06; organische Substanz $8,06 \%$, Salze $1,00 \%$; mithin im Ganzen $15,31 \mathrm{gr}$ organische Substanz, 1,90 gr Salze.

Die resorbirten Mengen berechnen sich, wie folgt:

\begin{tabular}{llcl} 
& Wasser & organische Substanzen & Salze \\
Eingeführt & $330 \mathrm{ccm}$ & $17,65 \mathrm{gr}$ & $3,17 \mathrm{gr}$ \\
Rückständig & $190 "$ & $15,31 "$ & $1,90 "$ \\
\hline Resorbirt & $140 \mathrm{~cm}$ & $2,34 \mathrm{gr}$ & $1,27 \mathrm{gr}$
\end{tabular}

Oder in Procenten der eingeführten Mengen:

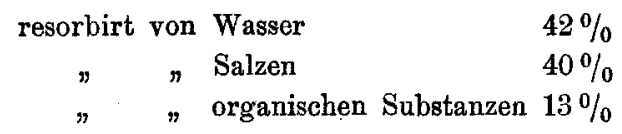

Die wie früher berechnete Lymphvermehrung während der Resorptionszeit beträgt nur $3,7 \mathrm{ccm}$; fast die ganze resorbirte Flüssigkeitsmenge ist also durch die Blutgefässe fortgeführt worden.

Das tibereinstimmende Resultat der beiden obigen Versuche lautet also dahin, dass bei der Resorption von Hundeserum im 
Hundedarme, welche die Mitwirkung osmotischer Triebkräfte ausschliesst, Wasser und Salze in nahezu demselben Verhältnisse, in welchem sie in dem eingeführten Serum vorhanden sind, zur Aufsaugung gelangen, während die organischen Substanzen in weit geringerer Proportion an der Resorption sich betheiligen.

Der Umstand, dass die Salze, welche fast allein die endos. motische Spannung der Flüssigkeit bestimmen, in dem gleichen Verhältnisse wie das Wasser entfernt werden, erklärt die nahezu vollkommene Constanz des $A$-Werthes der Darmflüssigkeit; welcher ja für die eingeführte und die rückständige Flïssigkeit fast derselbe ist. - Da aber $\Delta$ für diese beiden Flüssigkeiten nahezu gleich ist, muss auch die resorbirte Fltissigkeit nahezu denselben $\Delta$ Werth besessen haben, welcher wiederum dem Werthe für das Serum des Versuchsthieres fast gleich ist. Diese Feststellung führt zu einer neuen Frage von besonderer Schwierigkeit. Der Resorptionsvorgang setzt sich aus zwei Stadien zusammen. 1. Der Ueberführung der resorbirten Flïssigkeit aus dem Darm in das Zottenstroma; 2. Der Ueberführung aus dem letzteren in das Blut.

Dass das erste Stadium unter Umständen verlaufen kann, welche die Mitwirkung osmotischer Triebkräfte mit Sicherheit ausschliessen, ist durch Versuche des vorliegenden Paragraphen mit absoluter Sicherheit dargethan. Wie steht es mit dem zweiten Stadio? Die folgende Ueberlegung rechtfertigt diese Frage, giebt aber keine definitive Antwort.

Setzen wir den $\Delta$ Werth der resorbirten Flüssigkeit gleich dem Mittel der Werthe für das eingeführte und das riickständige Serum, so erhalten wir

$$
\begin{aligned}
& \text { in Versuch IX } A=0,580 \\
& \mathrm{X} \quad \Delta=0,608
\end{aligned}
$$

Das Serum des Versuchsthieres hat in IX $\Delta=0,622$, mithin ist der Unterschię von $A$ für das strömende Blut und die resorbirte Flissigkeit $0,622-0,580=0,040$; für den Versuch $\mathrm{X}$ ergiebt sich nach ähnlicher Berechnung der Unterschied nur zu 0,016 . Trotz dieses minimalen Unterschiedes der endosmotischen Spannungen, welchem nur eine minimale Triebkraft entspricht, geht die resorbirte Flüssigkeit fast ganz in das Blutgefäss über. Bei der Resorption vón Serum, welches durch Wasserverdampfung eingeengt worden ist, muss die trotzdem resorbirte Flüssigkeit ohne Zweifel ein höheres $A$ besitzen, als das strömende Blut (vergl. die 
Versuche des nächsten Paragraphen). Diesen Verbältnissen gegenüber drängt sich die Frage auf, ob wohl die Ueberfïhrung der resorbirten Flüssigkeit ans dem $\mathrm{Z}$ ot t e $\mathrm{nst} \mathbf{r}$ oma in d i e B lutb a b n e n durch Diffusion erklärlich sei, - eine Frage, die hier nur angedeutet sein mag; ihre Erledigung wird eine weitlänfige Untersuchung erfordern.

Ich darf diesen Paragraphen nicht schliessen, ohne zu erwähnen, dass bereits vor 25 Jahren C. V o it ${ }^{1}$ ) die Resorption von Blutserum im Darmcanal beobachtet hat, als er die Eiweissresorption studirte. Die von ihm beobachtete Thatsache fübrte Voit zu dem Schlusse, dass die Resorption nicht durch Diffusion zu Stande kommen könne. Wahrscheinlich steigere die Darmperistaltik den Druck im Darmlumen in hinreichender Weise, um die Flüssigkeit in die Schleimhaut hineinzupressen, - eine durch keinerlei Thatsachen gestützte Deutung. Die V o it'sche Beobachtung, vereinzelt wie sie war, ist bei der Discussion der Resorptionstheorie in der Literatur ganz ausser Betracht geblieben; anch ich habe sie erst bei nachträglicher Durchmusterung meiner Collectanea während des Niederschreibens dieser Arbeit aufgefunden und freue mich, sie wieder zu Ehren bringen zu können.

\section{\$ 4. Resorption von Chlornatrium-Lösungen.}

Die im vorigen Paragraphen erörterte Resorption von Hundeserum im Hundedarme bernht nicht auf osmotischen Triebkräften; denn es fehlen die Bedingungen für die Entwicklung derselben -, so lautet das zweifellose Ergebniss der Untersuchung. Die Triebkraft fuir den Strom der Darmfluissigkeit aus dem Darme heraus hann ihren Ursprung nur den Elementen der Darmwand selbst verdanken; nennen wir sie der Kürze balber die „physiologis che Triebkraft".

Naturgemäss wirft sich nunmehr die Frage auf, wie sich der Ablauf des Resorptionsprozesses gestaltet, wenn Darminbalt und Blut verschiedene osmotische Spannungen besitzen, so dass die Differenz derselben als os motis che Triebkraft wirkt? Wird

1) Voit und Bauer: Veber die Aufsaugung im Dick- und Dïnndarm. Ztschr. f. Biologie. Bd. V. 1869. S. 536. Tabelle auf S. 564. Versuch 14. 
diese physikalische Triebkraft neben der physiologischen zur Geltung kommen? Denn dass unter solchen Bedingungen die Diffusion allein den Resorptionsvorgang beherrscht, während die nachweislich zur Entwicklung eigener Triebkräfte in so hohem Grade befähigte Darmwand dem Spiele der einfach physikalisehen Kräfte in beschaulicher Ruhe das Feld überlässt, wird von vornherein Niemand annehmen wollen; viel eher erscheint es möglich; obschon ebenfalls nicht wahrscheinlich, dass besondere Einrichtungen der Darmwand die Diffusion ausschliessen, wie z. B. besondere Verhältnisse der Speicheldrïsen den Uebergang von Eisensalzen in das Secret verhindern, die doch so leicht ihren Weg in den Harn finden, oder wie das in mehr als halbprozentiger Lösung im Blutplasma vorhandene Kochsalz nicht in die rothen Blutkörperchen einzudringen vermag.

Ueber jene Fragen zu entscheiden wandte ich mich zu erneuter Untersuchung der schon vielfach studirten Resorption von Kochsalzlösungen, deren endosmotische Spannung mittelst der Gefriermethode mit der Spannung des Blutserums verglichen werden konnte.

Die endosmotischen Spannungen der Kochsalzlösungen fand ich im Durchsehnitte

$\begin{array}{ccccccc} & & & \text { beobachtet } & \text { berechnet } & \text { Unterschied } \\ \text { bei einem Gehalt von } & 2 \% & \text { zu } & A=1,246 & 1,400 & 0,154 \\ & 1,5, & , & 0,925 & 1,050 & 0,125 \\ 1, & \prime & \left.0,638^{1}\right) & 0,700 & 0,062 \\ 0,5, & , & 0,350 & 0,350 & \end{array}$

Ich habe schon oben erwähnt, dass meine Ziffern durchweg etwas höher liegen, als die Werthe anderer Autoren; ich bin nicht im Stande gewesen, die Ursache dieser Verschiedenheit aufaufinden. Sie kann nur darin liegen, dass ich im Verlaufe meiner anderthalbjährigen Beschäftigung mit diesen Dingen eine bestimmte Art zu manipuliren mir angewöhnte, besonders einen bestimmten Grad der Unterkühlung, eine bestimmte Geschwindigkeit des Umrührens während des Frierens, eine andere Temperatur des Kältegemisches benutzte (Vgl. oben $§ 2$ ), als sie von anderen Experimentatoren angewandt wurde. Den grossen Einfluss dieser vom Willen des Experimentators abhängigen Bedingungen hat Loom is

1) Nach andern Autoren 0,587-0,613. Vgl. § 2 . 
nachgewiesen. Da ich aber unter denselben Bedingungen den 4 -Werth des Serums bestimmt habe, und da es bei den mitzutheilenden Versuchen nur auf die Differenz der endosmotischen Spannungen von Blutserum und Kochsalzlösung, nicht aber auf die absoluten Werthe ankommt, thut jene Abweichung meiner Bestimmangen von denen meiner Vorgänger der Sicherheit der aus meinen Versuchen zu ziehenden Schlïsse nicht den mindesten Eintrag. Hinweisen möchte ich noch darauf, dass auch bei meinen Bestimmungen, wie bei allen früheren, die Abweichung der $\Delta$-Werthe von der Proportionalität mit den Concentrationen, welche durch die mit der Verdünnung fortschreitende Dissociation bedingt ist, klar hervortritt. Neben die empirisch gefundenen Werthe habe ich oben diejenigen gestellt, welche sich ergeben, wenn (mit Zngrundelegung des Werthes von 0,350 fitr die halbprozentige Lösung) das $\Delta$ für die höheren Concentrationen unter der Annahme der Proportionalität zwischen Gefrierpunktserniedrigung und Procentgehalt berechnet wird. Die Rechnungswerthe sind stets grösser, als die direct gewonnenen Werthe; der Unterschied steigt mit der Höhe der Concentration, wie es nicht anders sein kann, wenn nach der Voraussetzung der Physik die Dissociation mit steigender Concentration abnimmt.

Meine Werthe für das Serum des Hundes schwanken bei einer grösseren Zahl von Thieren zwischen $0,583-0,642$, also um eine Grösse von $0,059^{1}$ ). Die Schwankungen rühren z. Th. von dem versehiedenen Ernährungszustande der Thiere her, hauptsäcblich aber davon ab, ob zur Gewinnung des Serums eine nur kleine oder eine grosse Blutmenge entrogen worden war; bekanntlich verdünnt sich das Blut im letzteren Falle durch : schnelle Flüssigkeitsresorption aus den Geweben. Bei den ersten Versuchen habe ich diesen wichtigen Punkt übersehen, bei allen späteren dagegen bei der Verblutung der Thiere die ersten hundert Cubikcentimeter zur Serumgewinnung benutzt; in diesen Fällen ging $\Delta$ nicht unter 0,624 herunter. Ich glaube deshalb annehmen zu dürfen, dass für das Plasma des lebenden Hundes $A$ zwischen 0,624 und 0,642 liegt, also sehr nahe dem $\Delta$ einer einprozentigen Kochsalzlösung.

1) Dreser fand für menschliches Blutserum $A=-0,56$, bei einer mit Fleisch gefütterten Katze $A=0,66$ (für defibr. Blut); Hamburger für Pferdeserum 0,647 . 
Um eine hinreichende Einsicht in die Resorption von Kochsalzlösungen zu gewinnen, ist die Durchsicht eines sehr grossen Zahlenmaterials erforderlich, welehes übersichtlich für den Leser zu ordnen mir erhebliche Schwierigkeit macht. Ich glaube am zweckmässigsten zu verfahren, wenn ich einige Versuche voranstelle, in welchen in dieselbe Schlinge Lösungen von $0,3-1,5 \%$ Gehalt nach einander eingefüllt wurden, um den Ablauf der Resorption in ihrer Abhängigkeit von der Concentration zunächst im Allgemeinen kennen zu lehren. Dann aber wird die Resorption stärkerer Lösungen (über $1 \%$ ) und schwächerer (unter $0,75 \%$ ) im Besonderen zu erörtern sein.

a) Uebersich tsversuche.

Versuch XI. (14. 11. 93.)

Hund 14,1 Kilo. - Länge der Dämschlinge $120 \mathrm{~cm}$; Abstand vom Dickdarm $10 \mathrm{~cm}$.

Serum des Hundes: $A=0,634$; CINa-Gehalt 0,620 .

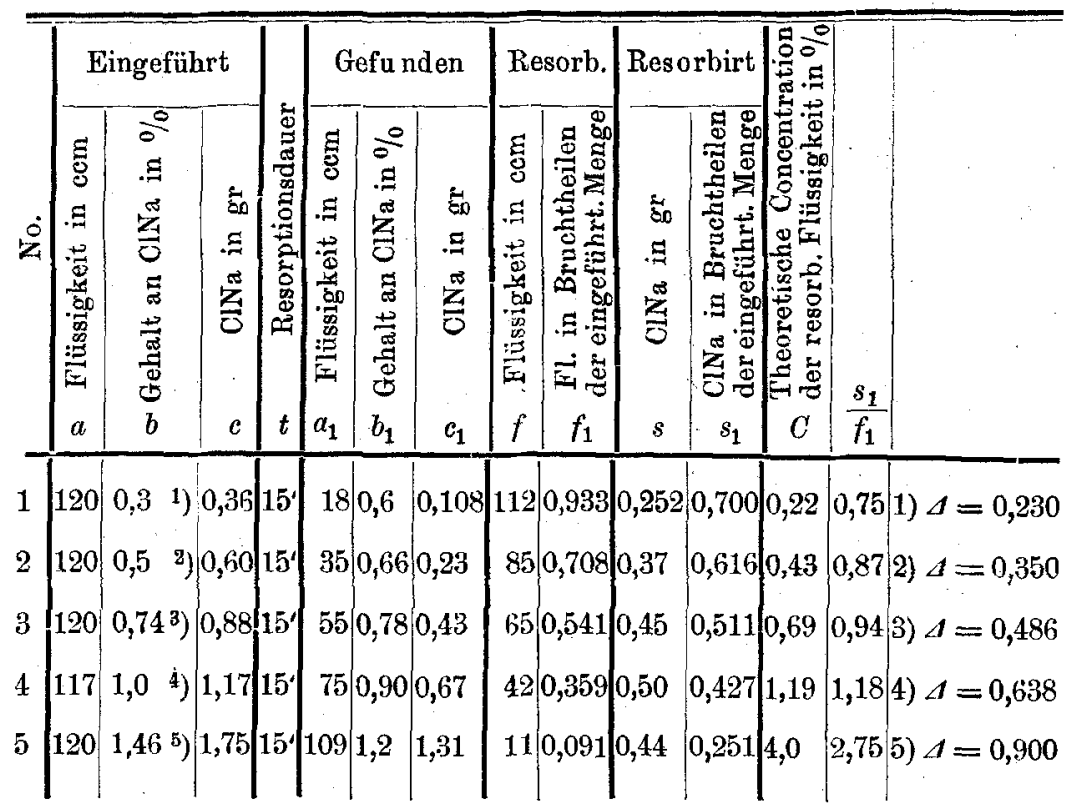


Versuch XII. (17. 11. 93.)

Hund 12 Kilo. - Darmschlinge $120 \mathrm{~cm} ; 5 \mathrm{~cm}$ vom Dickdarm. - Serum des Hundes: $A=0,642$. ClNa-Gehalt $0,69 \%$.

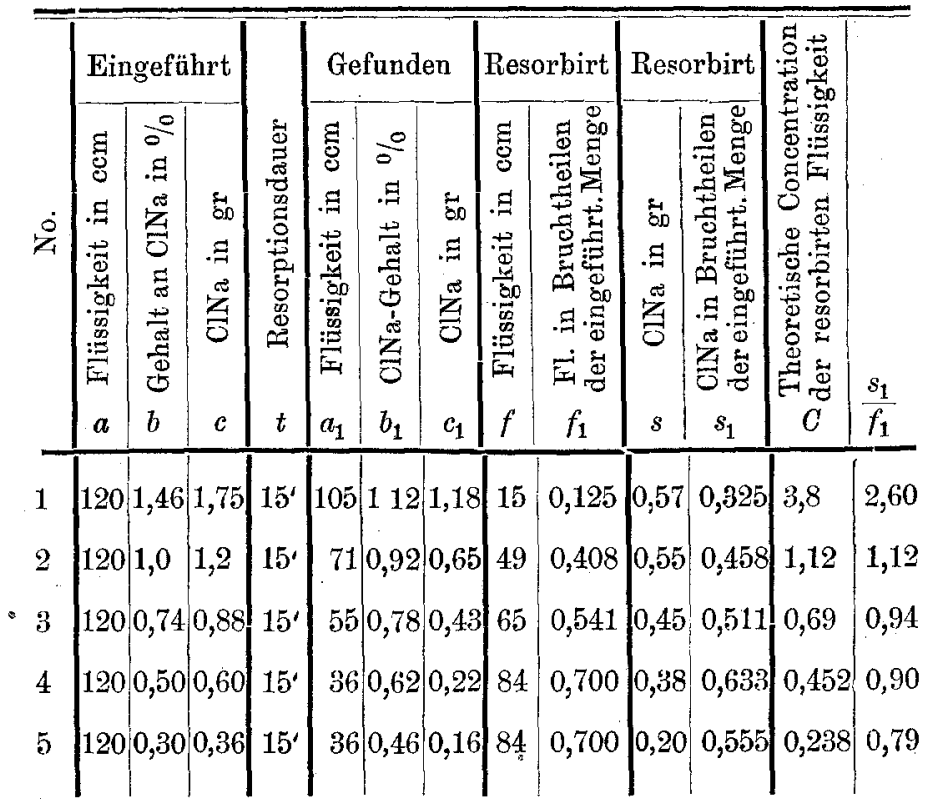

In den beiden voraufstehenden Versuchsreihen wurden dieselben Kochsalzlösungen verschiedener Concentration $\left(0,3-1,46^{\circ} \%\right)$ in dieselbe Darmschlinge eingefuillt; in Versuch XI in aufsteigender Folge, in Versuch XII in absteigender Reihe. Aus den Zahlen geht eine feste Gesetzlichkeit hervor, nach weleher sich mit Aenderung der Concentration die Resorptionsgeschwindigkeit des Wassers, des Salzes und das Verhältniss beider ändert. Zar schnellen Uebersicht ist in den Columnen $f$ and $s$ die absolute Menge des resorbirten Wassers und Salzes angegeben, in $f_{1}$ und $s_{1}$ sind die resorbirten Mengen ausgedritckt in Bruchtheilen der eingeführten Mengen. Die Columne $\frac{s_{1}}{f_{1}}$ drückt das Verhältniss der Resorptionsgeschwindigkeit von Wasser und Salz aus. Aus den Zablen lassen sich nun unmittelbar die folgenden Gesetzlichkeiten ablesen:

1. Mit steigender Concentration der in den Darm eingeführten Kochsalzlösung sinkt die absolute, wie die relative Menge des resorbirten Wassers. 
Vgl. Col. $f$ und $f_{1}$. Eine Ausnahme macht nur 4 und 5 in Vers. XII. Sie ist durch Nebenumstände bedingt, wie zahlreiche weitere Beobachtungen zeigen werden.

2. Mit steigender Concentration wächst die absolute Menge des resorbirten Salzes $(s)$, die relative Menge $\left(s_{1}\right)$ dagegen nimmt $\mathbf{a b}$.

Wiederum fallen die beiden obigen Versuche aus der Reihe ( 4 u. 5 in XII).

3. Das Verhälțiss der Salz- zur Wasserresorption $\left(\frac{s_{1}}{f_{1}}\right)$ ändert sich in folgender Weise: mit steigender Concentration nimmt die relative Wasserresorption schneller ab, als die relative Salzresorption. Das Verhältniss $\frac{s_{1}}{f_{1}^{-}}$ist für $0,3 \%$ etwa $0,75-0,79$. Von da ab wächst dasselbe, bis es bei $1,46 \%$ den Werth $2,6-2,75$ erreicht. Nahezu gleich der Einbeit $(0,94)$ ist es bei der Concentration $0,74 \%$.

Je geringer also die Concentration, desto grössere Geschwindigkeit hat der Wasserstrom im Verhältniss zu dem Salzstrome. Je mehr die Concentration wächst, desto mehr nimmt die Wasserresorption ab, die Salzresorption $z u$; doch wächst letztere nicht proportional der Concentration, sondern langsamer als diese.

Die obigen Thatsachen sind znm Theil schon in den aus meinem Institute hervorgegangen Arbeiten von Le ubus cher und von $\mathrm{G} \mathrm{umilewski}$ enthalten; doch werden sie sich jetzt auf Grundlage der Kenntniss der endosmotischen Spannungen des Blutes und der Darmflissigkeit in weit fruchtbarerer Weise verwerthen lassen.

Denn sie weisen mit Sicherbeit nach, dass osmotische Triebkräfte allein die beobachteten Erscheinungen nicht erklären, wie aus Folgendem hervorgeht:

1. Das Serum der beiden obigen Versuchsthiere batte $\Delta=0,634$ bezw. 0,642. Eine Kochsalzlösung von 1,46\% hat $A=0,900$. Nach den Gesetzen der Osmose miisste also ein Wasserstrom aus dem Blute nach der in den Darm gefüllten Kochsalzlösung eintreten, d. h. das Volumen derselben sich vergrössern. Wir sehen aber, dass umgekehrt aus jener höher gespannten Kochsalzlösung Wasser $\mathrm{zu}$ dem weniger gespannten Blute übertritt; die entgegengesetzt gerichtete osmotische Triebkraft wird durch eine Triebkraft anderer 
Natur und anderen Ursprunges iiberwunden. Von welcher Grösse diese physiologische Triebkraft im vorliegenden Falle mindestens sein müsse, lässt sich in rohen Ziffern schätzen. Da eine genaue quantitative Bestimmung bei den Schwankungen des Gefrierpunktes des Serums und bei den Differenzen meiner Gefrierpunktswerthe für die Kochsalzlösungen gegeniuber derjenigen anderer Autoren (s. oben) nicht angänglich ist, halte ich mich an auf die erste Decimale abgerundete Zahlen, indem ich für die Salzlösung von $1,46 \%$ für das Serum $A=-0,600$ setze. Da die osmotische Triebkraft der Differenz der Gefrierpunktserniedrigungen entspricht, würde sie gleich $A=-0,3$ sein. Nun lehrt die Physik, dass dem Werthe $A=-1,89$ ein Druck von 22,4 Atmosphären $=17,024 \mathrm{~m}$ Quecksilber entspricht; mithin einem Werthe von $A=-0,3$ ein Druck von $2700 \mathrm{~mm} \mathrm{Hg}$. Die physiologisehe Triebkraft muss also ausreichend sein, nicht bloss diesen Gegendruck zu tiberwinden, sondern dazu auch noch die geleistete Resorptionsarbeit zu Stande zu bringen.

Sie kann aber noch höhere Werthe erreichen; denn auch Kochsalzlösungen von $2 \%$ werden noch häufig resorbirt ${ }^{1}$ ). Da deren endosmotische Spannung in runder Zahl $A=-1,2$ ist, würde die osmotische Gegenkraft $A 1,2-0,6=0,6$ sein, also einem Druckwerthe von $5400 \mathrm{~mm} \mathrm{Hg}$ gleichen. Bei der Resorption können also durch die Darmwand Triebkräfte von ausserordentlich hohem Werthe entwickelt werden, unvergleichlich höher, als die in dem Capillardrucke nach der Filtrationstheorie der Lymphbildung wirksame Triebkraft.

2. Das Blutserum enthielt bei den beiden obigen Versuchen 0,62 bezw. $0,69 \%$ an Kochsalz. Bei Einfüllung einer Kochsalzlösung von 0,3 oder $0,5 \%$ in den Darm müsste nach den Gesetzen der Osmose Salz aus dem Blute zu der Darmflüssigkeit übertreten, denn die Partiarspannung des Kochsalzes im Blute ist höher als die Spannung desselben in der Darmflüssigkeit. (Vgl. oben $\S 2$ Satz 4). Die Versuche zeigen aber, dass Salz aus dem Darme verschwindet; bei einem Gehalte der Darmflüssigkeit von $0,3 \%$ gingen in $15^{\prime}$ nicht weniger als $70 \%$ der dargebotenen Salzmenge fort. Wie soeben von der Wasserresorption aus concentrirteren

1) Mitunter tritt bei Einführung der letzteren, namentlich im höheren Theile des Dünndarmes, Volumsvermehrung ein. Vgl. übrigens unten. 
Lösungen gezeigt worden ist, dass sie zur Diffusionstheorie in schroffem Widerspruche steht, so gilt das Gleiche hier von der Salzresorption aus den verdünnten Lösungen, deren Gehalt geringer ist, als der des Blutes.

Ein hartnäckiger Diffusions-Theoretiker könnte allerdings auf die folgende Hypothese verfallen, um seinen Standpunkt zu retten: Es ist hier und da die Vermuthung ausgesprochen worden, das Kochsalz sei im Blute nicht frei, sondern irgendwie, etwa an Eiweisskörper, gebnnden 1). Wenn dies richtig wäre, so könnte das Kochsalz im Serum eine geringere Spannung besitzen, als bei dem gleichen Procentgehalte in einfacher wässriger Lösung, ja eine geringere, als in einer wässrigen Lösung von kleinerem Salzgehalte. Wenn aber das Kochsalz in Lösungen von $0,3-0,5 \%$, in denen dasselbe frei ist, eine höhere Spannung besässe, als in dem Blutserum mit seinen 0,62-0,69 Procent, die sich ganz oder theilweise in gebundenem Zustande befändeu, so würde die Salzresorption aus jenen verdünnten Lösungen trotz alles Anscheins durch Diffusion zu Stande kommen können, ohne Betheiligung einer von der Darmwandung entwickelten besonderen Triebkraft.

Die Prüfung jener Hypothese ist leicht, wenn man Blutserum und verduinnte Kochsalzlösung durch eine todte Diffusionsmembran trennt. Die folgenden Versuche geben die Entscheidung.

\section{Versuch XIII (19. 12. 93).}

Ein Pergamentschlauch, der in $110 \mathrm{cem}$ Serum versenkt wird, enthält $30 \mathrm{ccm}$ einer Kochsalzlösung von $0,51 \%$ mithin $0,193 \mathrm{gr}$ CINa. Nach 24 Stunden finden sich in dem Schlauche $27 \mathrm{ccm}$ Flüssigkeit mit $0,64 \%$ ClNaGehalt, also $0,1728 \mathrm{gr}$ ClNa. Aus dem Blute sind also za der $0,51 \%$ igen Kochsalzlösung $0,1728-0,153=0,0198$ gr ClNa übergetreten.

Versuch XIV.

Dieselbe Anordnung, nur enthielten die $30 \mathrm{ccm}$ Kochsalzlösung in dem Schlauche nicht 0,51, sondern $0,3 \%$ entsprechend 0,09 gr. Nach 24 Stunden befanden sich in dem Schlauche $27 \mathrm{~cm} 0,58 \%$ Kochsalzlösung, entsprechend $0,156 \mathrm{gr}$. Cebergewandert waren also aus dem Serum in den Schlauch $0,156-0,09=0,066 \mathrm{gr}$ ClNa.

Bei dem ersten Versuche (Diffusiọn von Serum gegen $0,51 \%$ Lösung) hatte sich nach den obigen Zahlen die Salzmenge im Schlauche um 12,8\%, im zweiten Falle (Serum gegen $0,3 \%$ Salzlösung) um $73,3 \%$ vermehrt.

1) Durch solche Annahme hat man z. B. zu erklären versucht, dase die rothen Blutkörperchen gewöhnlich kein Kochsalz enthalten. 
Bei diesen Versuchen mit einer todten Membran tritt also ein, was nach den Diffusionsgesetzen erwartet werden muss: Wanderung des Salzes aus der Flissigkeit von höherem Gehalte (Serum) nach der Flüssigkeit von geringerem Gehalte (Kochsalzlösung von $0,3-0,5 \%$ ). Folglich muss dem höheren Gehalte des Serums auch eine höhere Spannung des Kochsalzes entsprechen. Die obige Ausflucht der Diffusionstheorie ist unhaltbar.

Es steht also fest: Aus Kochsalzlösungen, deren endosmotische Spannung weit höher ist, als die des Blutserums, wird Wasser, und aus solchen, in welcher die Spannung des ClNa geringer ist, als im Blute, wird Salz resorbirt; beide Thatsachen sind durch osmotische Triebkräfte nicht erklärlich, denn diese müssten eine umgekehrte Bewegung des Wassers bezw. Salzes herbeiführen, als sie thatsächlich stattfindet. Beide Thatsachen weisen mit Nothwendigkeit auf andersartige Triebkräfte hin, deren Ursprung nur in der lebenden Darmwand gesucht werden kann.

Es würde nun aber voreilig sein zu schliessen, dass es diese physiologischen Triebkräfte allein sind, welche den Resorptionsprozess beherrschen; ob dies der Fall sei oder ob nicht vielmehr, sobald die Bedingungen für Diffusion gegeben sind, auch die osmotischen Kräfte zu ihrem Rechte gelangen, so weit die physiologische Triebkraft derselben nicht entgegenwirkt, bedarf einer besonderen, eingängigen Untersuchung. Der Leser wolle der im ersten Paragraphen mit gutem Grunde von mir als Schema erwähnten Thonscheidewand mit eingesenkten galvanischen Platten sich erinnern, welche gleichzeitig Diffusion zulässt und neben derselben selbständig in die Stoffbewegung zwischen den beiderseitigen Lösungen eingreift, zu deren Trennung sie dient.

In der That weisen schon manche der bisherigen Erfahrungen darauf hin, dass die Vorgänge bei der Resorption sich nicht einfach auf die eine oder die andere Weise deuten lassen, dass vielmehr physiologische und physikalische Factoren in einander greifen, mit je nach den Bedingungen wechselnder Energie, um die Resorption von Salzlösungen herzustellen.

Die physiologische Triebkraft ist allein für sich wirksam, wo nach den vorliegenden Bedingungen osmotische Triebkräfte fehlen: bei der Resorption von Serum. Hier befördert sie Wasser und Salz in demselben Verhältnisse, in welchem sie dargeboten werden, aus dem Darme herans (S. oben $§ 3$ ). Ieh will es dem Leser nicht 
zumuthen, die Ueberlegungen mit mir durchzumachen, welche mich zu der hýpothetischen Annahme geführt haben, dass die Leistung der physiologischen Triebkraft auch anderen Lösungen gegenïber sich in derselben Weise äussert, d. h. dass sie, sobald sie überhaupt wirksam wird, immer Wasser und Salz in dem gegebenen Verhältnisse zur Resorption bringt.

$\mathrm{Zu}$ dieser physiologischen Leistung tritt, so nehme ich an, gegebenen Falls additiv die Leistung osmotischer Triebkräfte hinzu, wo solche vorhanden sind.

Von dem Boden dieser einfachen Auffassung aus erklären sich die Thatsachen, welche wir in Bezug auf die Resorption concentrirterer und verdünnterer Lösungen kennen gelernt haben, in befriedigender Weise. Um dies darzuthun, bin ich genöthigt, auf die Resorption von Kochsalzlösungen mit Benutzung eines breiteren Versuchsmaterials einzugehen, als es in den Versuchen XI und XII gegeben ist.

b) Specielle Besprechung der Resorption concentrirterer Kochsalzlös ungen $(1,0-1,5 \%)$.

Wenn eine Kochsalzlösung, deren Gehalt grösser ist, als der des Blutserums, zur Resorption gelangt, muss nach der oben entwickelten Anschauung aus der Gang der Freignisse folgender sein:

1. Eine gewisse Quantität der Lösung wird durch die physiologische Triebkraft - nach Analogie der Serumversuche - in unveränderter Zusammensetzung fortgeführt.

2. Es wird eine osmotische Triebkraft für das Kochsalz wachgerufen, weil die Spannung des Kochsalzes in der Darmflïssigkeit höher ist, als im Blute. In Folge derselben muss Salz aus dem Darm nach dem Blute ïberwandern, nm so mehr, je höher der Gehalt der Darmfluissigkeit an ClNa.

3. Da also die gesammte Resorptionsleistung sich aus der Resorption einer gewissen Menge von unveränderter Lösung ( $w$ Wasser $+s$ Salz) und einer gewissen Menge $\left(s^{1}\right)$ von Salz zusammensetzt, muss die theoretische (berechnete) Concentration der resorbirten Lösung $\left(\frac{s+s^{\prime}}{w} 100\right)$ höher sein, als die der eing eführten Lösung $\left(\frac{s}{w} 100\right)$; der Unterschied muss um so grösser sein, je höher die Concentration der letzteren. 
Die Zahlen der folgenden Tabellen II und III zeigen, dass diese Folgerungen aus der Theorie mit der Wirklichkeit übereinstimmen. Die Colnmne $C$ enthält die "theoretische Concentration" der resorbirten Fliissigkeit, d. h. die Concentration, welche man erhält, wenn man sich die gesammte resorbirte Salzmenge in der resorbirten Wassermenge gelöst denkt.

Tabelle II bezieht sich auf Lösungen von 1,46-1,52\%; der Werth $C$ liegt zwischen 1,9\% (bei sebr langer Resorptionsdauer) und $8 \%$.

Tabelle III betrifft Lösungen von $1,0-1,03 \% ; C$ schwankt zwischen 1,03 und $1,26 \%$, ist also durchweg niedriger als in Tabelle II.

4. Um noch unter andrer Form zu zeigen, in welchem Maasse die resorbirte Flüssigkeit sich von der dargebotenen unterscheidet, babe ich noch folgende Berechnungen durchgeführt:

a) Unter der Columne $f_{2}$ ist berechnet, wie viel Wasser hätte resorbirt werden muissen, wenn das resorbirte Salz $(s)$ in einer Lösung von der Concentration der eingeführten Flüssigkeit aufgenommen wäre; die unter $f_{2}$ verzeichneten Zahlen, welche ich als "Flïssigkeitsäquivalent des resorbirten Salzes" bezeichne, sind ausnahmslos grösser, als die thatsächlich resorbirten Wasserquantitäten (Col. $f$ ). Die Columne $f-f_{2}$ gibt deshalb ausnahmslos negative Werthe, und zwar in Tab. II (Concentrationen 1,46-1,52\%) höhere, als in Tab. III (Concentrationen $1,0-1,03 \%$ ), was der von mir aufgestellten Hypothese entsprechend ist.

b) Unter Columne $s_{2}$ ist die Salzmenge berechnet, welche zur Resorption hätte gelangen müssen, wenn die resorbirte Flüssigkeit einen Salzgehalt gleich der eingeführten besessen hätte („Salzäquivalent der resorbirten Flüssigkeit"). Die Werthe $s_{2}$ sind ausnahmslos kleiner als die thatsächlich resorbirten Salzmengen $s$; demnach ist die Differenz $s-s_{2}$ durchgängig positiv und wiederum, in Uebereinstimmung mit der Theorie, fuir die höheren Concentrationen der Tab. II ausnahmslos grösser, als für die geringeren der Tab. III.

5. Allem Voraufgehenden entsprechend gestaltet sich auch der Werth $\frac{s^{1}}{f_{1}}$, d. h. das Verhältniss der Resorptionsgeschwindigkeit des Salzes zu der des Wassers. Jener Werth ist ausnahmslos 
Neue Versuehe über die Aufsaugung im Dünndarm.

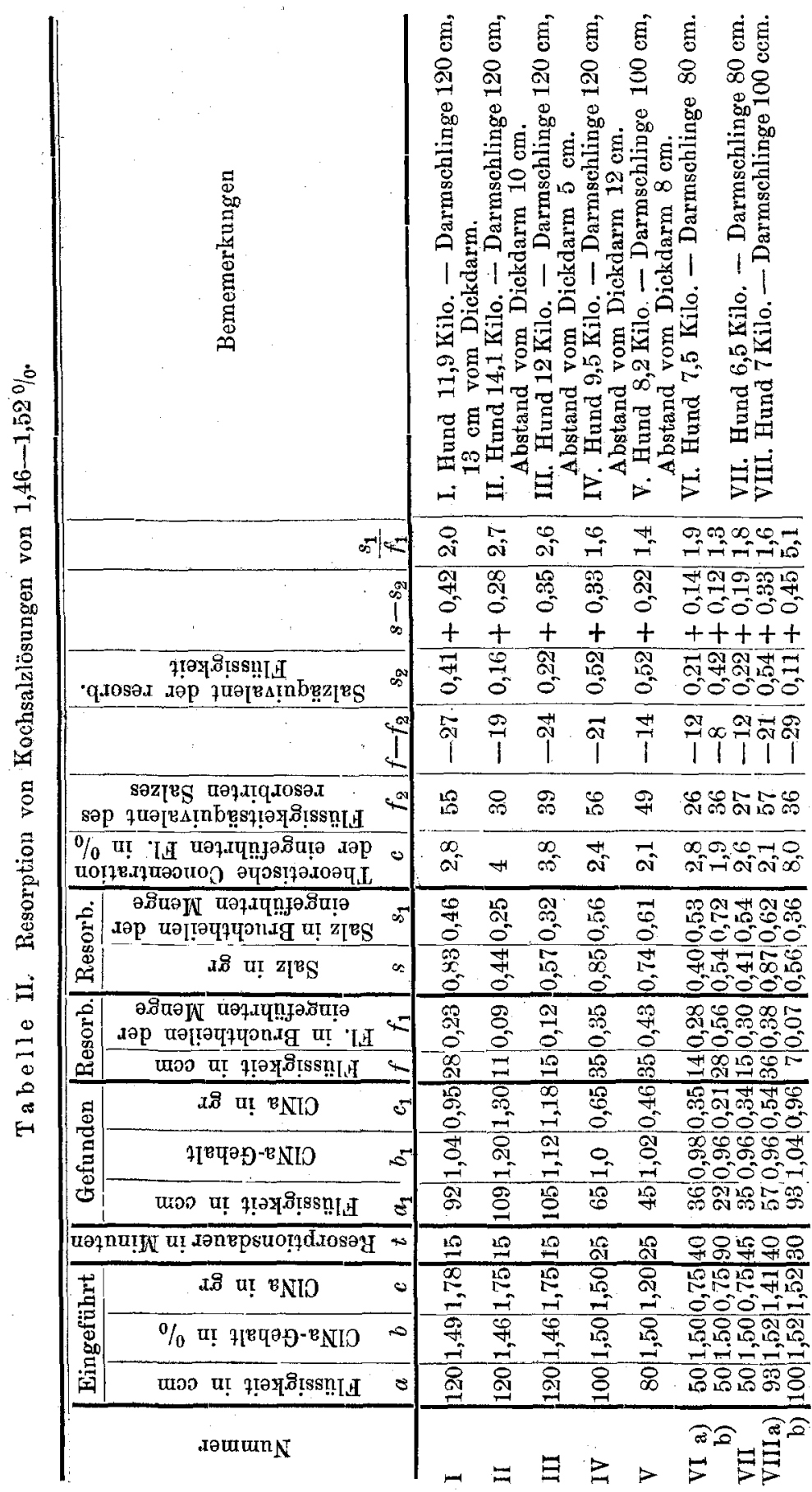




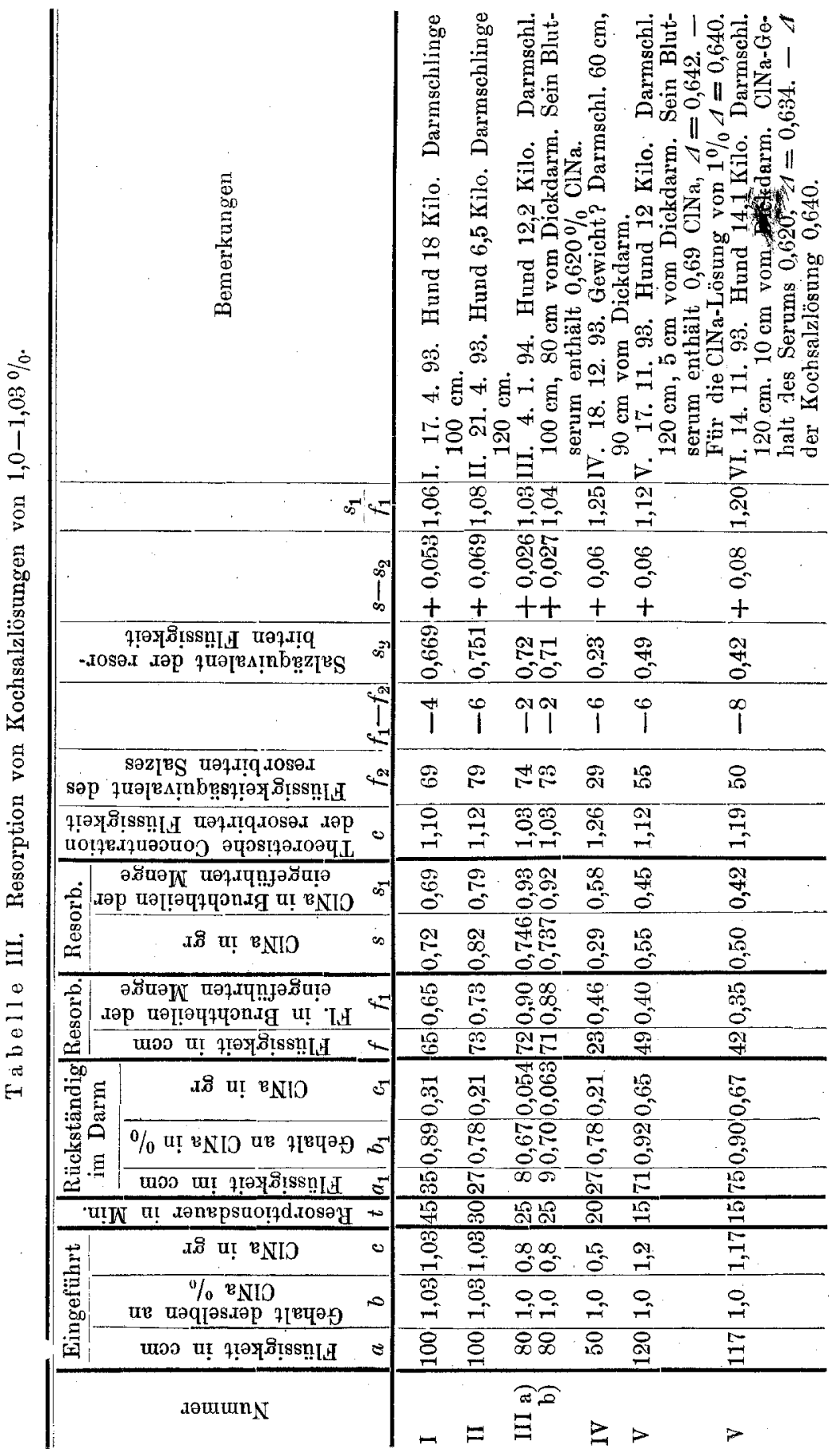


grösser als 1; er liegt für die höheren Concentrationen zwischen 1,3 und 5,1 , fir die geringeren zwischen 1,03 und 1,25 .

Die Steigerung des Salzgehaltes in der Darmflissigkeit hat also den Einfluss, die resorbirten Salzmengen in die Höhe zu treiben, weil die Salzdiffusion nach dem Blute mit steigender Concentration der Darmfliissigkeit zunimmt. Aber sie hat noch einen andern Einfluss: indem mit dem Salzgehalte die endosmotische Spannung der Darmflüssigkeit wächst, wird nicht bloss eine osmotische Triebkraft für das Salz aus dem Darme nach dem Blute hin, sondern auch eine solche für das Wasser in umgekebrter Richtung wachgerufen. Letztere wirkt der physiologischen Triebkraft entgegen; die durch letztere bedingte Flüssigkeitsresorption sinkt um so mehr, je höher die osmotische Gegenkraft ist. Von einem gewissen Concentrationsgrade ab wird die Flüssigkeitsresorption aufgeboben, während die Salzresorption fortbesteht, und jenseits desselben tritt ein Wasserstrom in umgekehrter Richtnng, d. h. im Sinne der osmotisehen Triebkraft vom Blute in den Darm hinein auf: das Volumen der Darmflüssigkeit vergrössert sich, während der Salzstrom nach dem Blute hin nach wie vor fortdanert.

Die Grenzconcentration, bei welcher die Flüssigkeitsresorption aufhört, scheint etwa bei einer Salzconcentration von ungefähr $2 \%$ zu liegen.

Wie sich bei so hohen Concentrationen die Verbältnisse gestalten, lässt sich nach folgenden Beobachtungen beurtheilen.

Versuch XVI (12. 2. 94).

Hund 7,2 Kilo, Länge der Schlinge $100 \mathrm{ccm}$, Abstand vom Dickdarm $8 \mathrm{~cm}$.

\begin{tabular}{|c|c|c|c|c|c|c|}
\hline I. & $\begin{array}{r}9^{\mathrm{h}} 6^{\prime} \text { eingefällt } \\
26^{\prime} \text { gefunden }\end{array}$ & $\begin{array}{l}80 \mathrm{ccm} \\
80\end{array}$ & $\begin{array}{c}\mathrm{ClNa} \\
\eta\end{array}$ & $\begin{array}{l}1,98 \% \\
1,20\end{array}$ & $\begin{array}{c}\text { entspr. } \\
n\end{array}$ & $\begin{array}{l}1,58 \mathrm{gr} \\
0,96\end{array}$ \\
\hline sorbirt in & $20^{\prime}$ & $0 \mathrm{ccm}$ & & & & $0,62 \mathrm{gr}$ \\
\hline
\end{tabular}

II. $\quad 9^{\mathrm{h} 30^{\prime}}$ eingefällt $80 \mathrm{ccm}$ ClNa $1,98 \%$, entspr. $1,58 \mathrm{gr}$

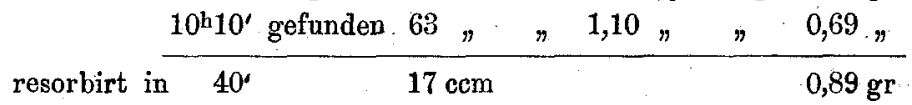

III. $\quad 10^{\mathrm{h}} 13^{\prime}$ eingefällt $80 \mathrm{ccm}$ CINa $1,98 \%$, entspr. $1,58 \mathrm{gr}$

$\frac{11^{\mathrm{h}} 13^{\prime} \text { gefunden } 42 ", 0,96 ", \quad 0,40 n}{38 \mathrm{~cm}}$

E. Pflüger, Archiv f. Physiologie. Ba. 56 . 
Die endosmotischen Spannungen betrugen

für die Kochsalslösung von 1,98 . . . . . . $A=1,243$

" " rückständige Flüssigkeit ${ }^{1}$ ) bei Versuch I $A=0,916$

$" \quad " \quad " \quad " \quad$ II $A=0,802$

$" \quad " \quad n \quad$ " III $A=0,790$

Alle Werthe von $\mathcal{A}$ für die Darmflüssigkeiten liegen über dem Werthe für das Serum (höchstens 0,642). Die Resorption der Fliissigkeit geht hier also trotz ständiger osmotischer Gegenkraft vermöge der physiologischen Triebkraft vor sich. So lange die osmotische Gegenkraft auf ihrem Maximum ist, wird die physiologische Triebkraft in dem Grade überwunden, dass Flüssigkeitsresorption nicht stattfindet. Allmählich aber nimmt die Grösse des osmotischen Gegendruckes ab, indem Salz durch Diffusion entfernt wird; in dem Masse als dies geschieht, tritt Flüssigkeitsresorption ein, um so stärker, je mehr durch Salzdiffusion die osmotische Gegenkraft sinkt. So erklärt es sich, dass in 20 Minuten noch gar keine Flüssigkeit verschwindet, in 40 Minuten dagegen 21 Procent und in 60 Minuten 47 Procent der Flüssigkeit entfernt werden: die ursprïngliche osmotische Gegenkraft (entsprechend der Differenz der Gefrierpunkte $A=1,243-0,642=0,601$ ) ist in 20 Minuten auf $0,916-0,642=0,274$, in 40 Minuten auf 0,802 $-0,642=0,160$ und in 60 Minuten auf $0,740-0, \mathbf{b} 42=0,098$ gesunken. Damit wird der physiologisehen Resorptionskraft, die ursprïnglich völlig lahm gelegt war, in steigendem Masse die Möglichkeit gegeben, sich geltend zu machen.

Ganz Aehnliches gilt bis zu eimer gewissen Grenze anch dann, wenn die Concentration der Darmflüssigkeit noch höher als $2 \%$ genommen wird. Bei $2 \frac{1}{2}-3 \%$ tritt immer zunächst Volumsvermehrung des Darminhaltes ein. Indem sich aber gleichzeitig die Concentration desselben durch osmotische Fortführung von Salz verringert, kann schliesslich eine hinreichend niedrige Concentration erreicht werden, um der physiologischen Triebkraft ihre Arbeitsleistung zu ermöglichen. So bewirkt die physikalische Diffusion für die physiologiscbe Triebkraft Befreiung von den Fesseln,

1) Diese im Darm rückständigen Flüssigkeiten haben stets ein etwas höheres $\mathcal{A}$, als dem Kochsalzgehalte entspricht, weil in die Flüssigkeit immer etwas kohlensaures Natrium aus der Darmwand (Schleim der Becherzellen, Secret der Drüsen) übergeht. 
welche zu hohe endosmotische Spannung des Darminhaltes ihr anlegte, indem sie diese Spannung vermindert.

Freilich gibt es eine Grenze; schon eine dreiprocentige Kochsalzlösung schädigt die Elemente der Darmwand (das Epithel) so erheblich, dass dadurch seine Leistungsfähigkeit wesentlich beeinträchtigt wird ${ }^{1}$ ).

c) Specielle Besprechung der Resorption verdünnterer Koehsalzlösungen $(0,3-0,5 \%)$.

Dass die Resorption auch dieser Lösungen nicht durch einfache Diffusion geschieht, ist bereits oben ausführlich aus einander

1) Bei den Aufstellungen der obigen Tabellen habe ich nicht in Rechnung gezogen, dass wenn $\mathrm{CINa}$ in das Blut hinein diffundirt, dafür eine dem endosmotischen Aequivalent entsprechende Wassermenge aus dem Blute in den Darm übertritt. Die Berechtigung, diese Wassermenge zu vernachlässigen, liegt darin, dass jhre Grösse, weil es sich um Diffussion von nur kleinen Bruchtheilen eines Gramm Kochsalz handelt, sehr gering ist gegen die rebirten Wassermengen. - Auch die etwaige Secretion von Darmsaft habe ich nicht berücksichtigt. Gumilewski (in der oben citirten Arbeit) stellte die Darmsaftsecretion in der Weise in Rechnung, dass er die Alcalescenz der Darmflüssigkeit nach ihrer Entleerung bestimmte, sie auf kohlensaures Natrium bezog und einen constanten Gehalt des Darmsaftes von 0,5\% Soda annahm. Allein bei meinen Versuchen an abgebundenen Schlingen (G.'s Versuche wurden an einer Vella'schen Schlinge angestellt) lagen die Dinge ganz anders als bei G. Ich habe die Alcalescenz sehr oft bestimmt; $10 \mathrm{ccm}$ der Darmflüssigkeit entsprachen meist weniger als $1 \mathrm{ccm} 1 / 10$ Normalschwefelsäure; mitunter stieg die Alcalescenz auf 1 , höchstens $2 \mathrm{ccm}$. Unter denselben Bedingungen schwankte die Alcalescenz bei verschiedenen Versuchen in hohem Grade. Bei wiederholter Füllung derselben Schlinge sank sie oft anf ein Minimum. Diese Schwankungen weisen auf sehr veränderliche Quellen der Alcalescenz hin. In der That tragen zu derselben theils kleine Reste von Verdauungsflüssigkeiten bei (war die Flüssigkeit durch Galle etwas gelblich, so ergab sich stets stärkere Alcalescenz), ferner Schleim der im untern Darmabschnitte zahlreichen Becherzellen, in den Darm diffundirende alkalische Salze des Blutes, endlich etwas Drüsensecret. Ich halte es deshalb für richtiger, die Alcalescenz ganz bei Seite zu lassen, als sie allein auf Drüsensecretion zu beziehen. Schliesslich kommt es, wie der Erfolg zeigt, gar nicht darauf an, ob: man sie nach Gumilewski in Rechnung stellt oder nicht. Wir sind beide bezüglich der Kochsalzresorption zu derselben Grundthatsache gelangt, dass nämlich aus Lösungen unter 0,6-0,7\% das Wasser schneller schwindet, als das Salz, aus Lösungen höherer Concentration umgekehrt das Salz schneller als das Wasser. (Vgl. Gu milewski's Abh. S. 582 u. 583.) 
gesetzt, denn beì uncomplicirtem Spiel der osmotischen Kräfte müsste aus der Blutfliussigkeit, deren Kochsalzgehalt über $0,6 \%$ beträgt, in den Darm Kochsalz überwandern, wie es in der That geschieht, wenn Serum und Salzlösungen jener Concentration durch eine Scheidewand ron Pergamentpapier von einander getrennt sind (s. oben Versuch XIII und XIV). Der Versuch lehrt aber, dass jene Lösungen Salz an das Blut abgeben, im Widerspruche zur Diffusionstheorie.

Von dem Boden meiner Hypothese aus lassen sich die Erscheinungen, welche bei der Resorption jener Lösungen beobachtet werden, in befriedigender Weise deuten. Die Gesammtresorption setzt sich wiederum aus zwei Theilen zusammen: 1. es wird eine gewisse Menge lösung in der dargebotenen Concentration $\left(\frac{s}{w}-100\right)$ dureh die physiologische Triebkraft entfernt. 2. Da die endosmotische Spannung der 0,3-0,5\% igen Kochsalzlösungen erbeblich geringer ist, als die der Blutflüssigkeit, wird ein osmotischer Wasserstrom aus dem Darme nach dem Blute hin eintreten, welcher $\left(w_{1}\right)$ Wasser entführen mag. Die theoretische Concentration der resorbirten Lösung $\left(\frac{s}{2 v+w_{1}} 100\right)$ muss also geringer sein, als die Concentration der ursprïnglichen Lösung, während gleichzeitig die Concentration des Darminhaltes steigt, weil durch die Gesammtresorption (physiologische und physikalische) das Wasser in schnellerem Verbältnisse fortgeführt wird als das Salz.

Die Zahlẹn der Tabelle IV, welche nach denselben Principien berechnet ist, wie die Tabelle II und III, bestätigen die obigen, durch meine Hypothese geforderten Folgerungen. Sie lehren:

1. Die theoretische Concentration der resorbirten Flüssigkeit $(C)$ ist stets geringer, als die Concentration der in den Darm eingeführten Lösung $(b)$ (für die stärkeren Salzlösungen gilt das Umgekehrte).

2. Die Concentration der Darmflüssigkeit $\left(b_{1}\right)$ steigt wäbrend der Resorption, denn $b_{1}$ ist immer grösser als $b$ (im Gegensatze zu Tab. II und III).

3. Das Fluissigkeitsäquivalent (im oben definirten Sinne) des resorbirten Salzes $\left(f_{2}\right)$ ist immer kleiner als die resorbirte Flüssigkeitsmenge $\left(f_{1}\right)$, daher $f_{1}-f_{2}$ stets positiv. Für die stärkeren Lö- 
Neue Versuche über die Aufsaugung im Dünndarm.

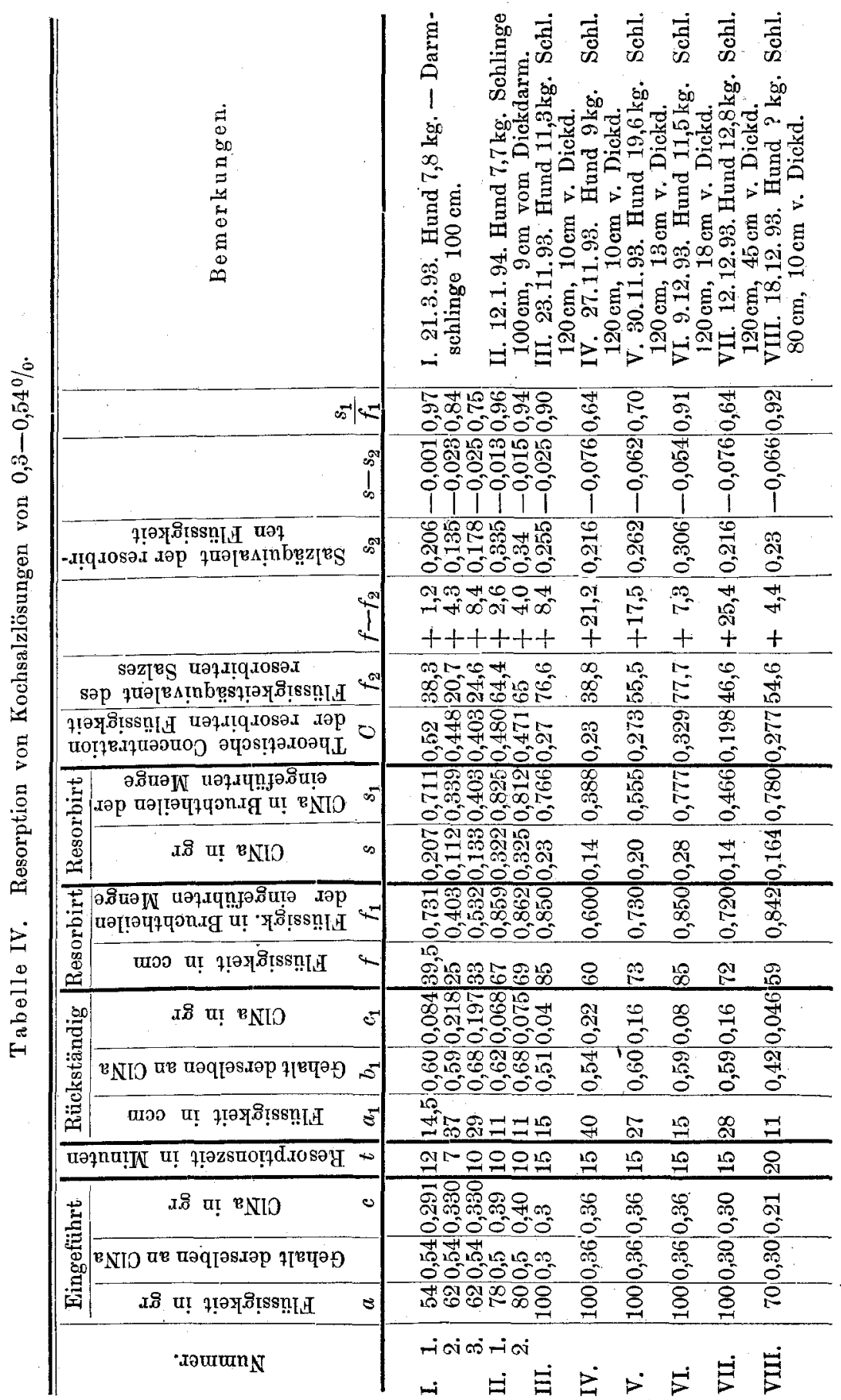


sungen in Tab. II und III war dieser Werth ausnahmslos negativ.

4. Das Salzäquivalent der resorbirten Flüssigkeit $\left(s_{2}\right)$ ist stets grösser, als die wirklich resorbirte Salzmenge $(s)$, daher $s-s_{2}$ immer negativ. In Tab. II und III war dieser Werth stets positiv.

5. Der Werth $\frac{s_{1}}{f_{1}}$, welcher das Verhältniss der Resorptionsgescbwindigkeit des Salzes zu der des Wassers ausdrückt ${ }^{1}$ ), ist stets kleiner als 1 ; in Tab. II und III war derselbe immer grösser. Jener Werth nähert sich um so mehr der Einheit, je weiter die Resorption vorgeschritten, je geringer der Flïssigkeitsrest im Darm ist, wie ein Vergleich der Versuche I, II, III, VI, VIII mit den übrigen Versuchen der Tabelle ergibt. Dieses Verhalten ist selbstverständlich, denn wenn zuletzt alle Flüssigkeit und alles Salz verschwunden ist, muss $\frac{s_{1}}{f_{1}}=1$ werden.

Alle diese Thatsachen stehen in vollkommner Uebereinstimmung mit der Hypothese, dass die Gesammtresorption sich aus einem physiologischen und einem physikalischen (osmotischen) Theile zusammensetzt.

d) Zusammenfassung der bisherigen Ergebnis se. Weitere A uf gabe.

Fassen wir das Hauptergebniss der die Resorption von Kochsalzlösungen betreffenden Versuche ins Ange, ohne alle Einzelheiten zu wiederholen. Die Annahme einer besonderen physiologischen Triebkraft wird erzwangen: 1. durch die Thatsache der Serumresorption; 2. durch die Thatsache der Wasserresorption aus Kochsalzlösungen, deren endosmotische Spannung höher ist, als die der Blutflüssigkeit; 3. durch die Thatsache der Salzresorption aus Lö. sungen, in welchen die endosmotische Spannung des Kochsalzes geringer ist, als in der Blutflüssigkeit.

Alle diese absolut sicheren Thatsachen sind durch Osmose nicht zu erklären; sie fordern gebieterisch die Annahme andrer als der osmotischen Triebkräfte.

1) Genau genommen vergleicht der Quotient $\frac{s_{1}}{f_{1}}$ die rel a tive Salzresorption mit der relativen Wasserresorption. Er kann als "Resorptionscoefficient" bezeichnet werden. 
Dass letztere bei der Resorption mitwirken, wenn die Bedingungen zur Entwicklung derselben gegeben sind, ist durch die sub b und e erörterten Thatsachen mit höchster Wahrscheinlichkeit nachgewiesen; ganz besonders wichtig für die Beurtheilung der Frage ist der Umstand, dass Salzresorption unter Bedingungen stattinden kann, unter denen die Wasserresorption aufgehoben ist (vgl. Versuch XVI, I), ja selbst wenn diese negativ geworden ist, d. h. wenn unter Ueberwindung der physiologisehen Trieblkraft Wasser aus dem Blute in den Darm ïbertritt.

Je verwickelter die Verhältnisse bei der Resorption liegen, desto mehr erscheint es wünschenswerth, durch andre Versuchsweisen die aus den bisher mitgetheilten Ergebnissen gezogenen Schlussfolgerungen noch weiterhin zu prüfen.

Eine solche Prufung ist aber auf folgendem Wege denkbar: Die Gesammtresorption concentrirterer Lösungen $(1,0-1,5 \%)$ setzt sich, wie ich nochmals wiederhole, aus zwei Componenten zusammen: 1. Eine gewisse Menge Wasser $(w)+$ einer gewissen Menge von Salz (s) wird durch die physiologische Triebkraft aus dem Darme entfernt. Das Verbältniss $\frac{s}{w}$ ist nach unsrer Hypothese dasselbe, wie in der eingeftihrten Lösung. 2. Eine andre Menge von Salz $\left(s^{1}\right)$ wird durch Diffusion in das Blat iibergeführt. Die Gesammtresorption ist also $(w+s)+s^{1}$. Wenn es nun gelänge, die physiologische Triebkraft durch irgend welche Einwirkungen abzuschwächen, so würde $(w+s)$ sinken, $s^{1}$ unverändert bleiben, also die gesammte Wasserresorption in stärkerẻm Masse sinken mïssen, als die Salzresorption, da erstere ganz und gar, letztere nur zu einem Theile von der physiologischen Triebkraft abhängt.

Bei den minder concentrirten Lösungen $(0,3-0,5 \%)$ muss eine derartige, die physiologische Triebkraft herabsetzende Einwirkung andre Folgen haben. Die Gesammtresorption setzt sich hier aus dem physiologischen Gliede $(w+s)$ und dem physikalischen Gliede $w^{1}$ zusammen (vgl. die Ausführungen sub c). In diesem Falle wird Schwächung der physiologischen Triebkraft die Salzresorption in stärkerem Masse afficiren, als die Wasserresorption, da erstere allein auf die physiologischen Hilfsmittel der Resorption angewiesen ist, letztere durch die osmotischen Triebkräfte unterstiitzt wird. 
Nach langem Suchen habe ich ein Mittel gefunden, die physiologische Triebkraft in der besprochenen Weise abzuändern: dasselbe besteht in dem Zusatze einer geringen Menge Fluornatrium zu den zu resorbirenden Salzlösungen.

\section{§. Einwirkung von Fluornatrium anf den Resorptions- vorgang.}

Die allgemeinen Wirkungen des Fluornatrium auf den Organismus, wenn dasselbe in das Blut eingeführt wird, sind bereits mehrfach Gegenstand der Untersuchung gewesen. Ta p p e i n e r z. B. sah einen Hund in 3 Stunden sterben, nachdem dieser pro Kilo Körpergewicht $0,15 \mathrm{gr}$ erhalten hatte. Ein andrer, dem pro Kilo etwas weniger als $0,1 \mathrm{gr}$ injicirt wurde, zeigte keine auffallenden Erscheinungen.

Ich will den Leser nicht mit den Vorversuchen ermüden, welche ich angestellt habe, um zu ermitteln, ob das Fluornatrium für den oben ins Auge gefassten Zweck brauchbar sei. Ich führte dasselbe theils in das Blut, theils mit der zu resorbirenden Kochsalzlösung in den Darm ein.

Bei der Einführung in das Blut fiel der Einfluss anf die Darmresorption sehr ungleichmässig aus, wie folgende kleine Uebersichtstabelle zeigt. Bei jedem Versuche wurden in eine Darmschlinge $50 \mathrm{cem}$ Kochsalzlösung von $0,6 \%$ gefüllt, nachdem kurz zuvor die angegebne Dosis Fluornatrium in die v. facialis injicirt worden.

\begin{tabular}{|c|c|c|c|c|}
\hline & $\begin{array}{c}\text { Injicirt an } \\
\text { FlNa } \\
\text { pro Kilo }\end{array}$ & $\begin{array}{c}\text { Resorbirt im } \\
\text { Darme. }\end{array}$ & $\begin{array}{c}\text { Nach } \\
\text { Stunde }\end{array}$ & Bemerkungen \\
\hline $\begin{array}{cc}\text { I } & \\
\text { II } & \\
\text { III } & 1) \\
& 2) \\
\text { IV } & \\
\text { V } & 1) \\
& 2)\end{array}$ & $\begin{array}{l}0,054 \\
0,005 \\
0,015 \\
0,020 \\
0,025 \\
0.028 \\
0,035\end{array}$ & $\begin{array}{l}0 \\
50 \\
50 \\
26 \\
32 \\
50 \\
10\end{array}$ & $\begin{array}{l}1^{1 / 2} / 2 \\
1^{1 / / 2} \\
1 \\
2^{1 / 3} \\
1^{1 / 3} \\
1^{1 / 2} / 2 \\
1^{3} / 4\end{array}$ & $\begin{array}{l}\text { Das Thier starb nach } \\
11 / 2 \text { Stunde. }\end{array}$ \\
\hline
\end{tabular}

In den tödtlich verlaufenden Fällen fand ich die ganze Darmwand im Zustande hochgradiger Blutanschoppung, das Epithel zerstört, während auffallender Weise das Epithel der Luftröbrenschleimhaut so wenig gelitten hatte, dass seine Zellen lebhaft 
flimmerten. Die weitere Untersuchung der örtlichen Wirkungen nach Injection von Fluornatrium in das Blat muss späterer Arbeit vorbehalten bleiben. Im Augenblicke würrde sie mich zu sehr von meinem eigentlichen Ziele abgelenkt haben, welches sich durch Einführung jenes Salzes in den Darm selbst erreichen liess.

Bei Einführung einer Fluornatriumlösung von $1 \%$ tritt im Darme enorme Blutcongestion und Zerstörung der Schleimhaut auf. Durch allmähliche Verminderung der Concentration liess sich eine Grenze feststellen, bei welcher das Epithel nach Ausweis des Mikroskopes normal bleibt, während die Resorptionsfunction wesentlich leidet: es tritt also eine functionelle, aber nicht eine anatomisch nachweisbare Schädigung desselben ein. Die folgenden Uebersichtstabellen geben über die Art der Wirkung Auskunft.

Die Zahlen der nachstehenden Tabelle V lehren:

1. Bei Zusatz von $0,04-0,05 \%$ Fluornatrium zu Kochsalzlösungen von $1,05-1,5 \%$ sinkt die Wasserresorption in hohem Masse. Man ersieht diese Thatsache am besten aus den Ziffern der Columne $f_{1}$, welche die resorbirten Flüssigkeitsmengen in Bruchtheilen der eingefiihrten ausdrücken.

Die geringe Aenderung der endosmotischen Spannung durch den Zusatz des Fluorsalzes ist nicht entfernt im Stande, die enorme Wirkung zu erklären.

2. Die Salzresorption sinkt ebenfalls, aber in weit geringerem Masse als die Wasserresorption, wie obne Weiteres ein Vergleich der Ziffern in den Reihen $s_{1}$ und $f_{1}$, sowie der Quotienten $\frac{s_{1}}{f_{1}}$ ergibt $\left.^{1}\right)$.

3. Die theoretische Concentration der resorbirten Flüssigkeit nimmt zu (vgl. Col. C), was nach dem bereits Gesagten selbstverständlich erscheint.

Die Consequenzen dieser Verhältnisse drücken sich nicht minder deutlich in den Zahlen der Col. $f-f_{2}$ und $s-s_{2}$ aus, uber

1) Setzt man die vor der Fluorwirkung resorbirten Wasser- resp. Salzmengen ( $f$ und $s$ ) gleich 1, so sind dieselben durch die Fluorwirkung heruntergesetzt auf

$\begin{array}{ccrlll} & & & & f & s \\ \text { in } & \text { Versuch } & \text { I 2) } & 0,228 & 0,56 \\ & & \text { II 2) } & 0,28 & 0,68 \\ " & \# & \text { III 2) } & 0,36 & 0,50 \\ " & \# & \text { IV 2) } & 0 & 0,64\end{array}$




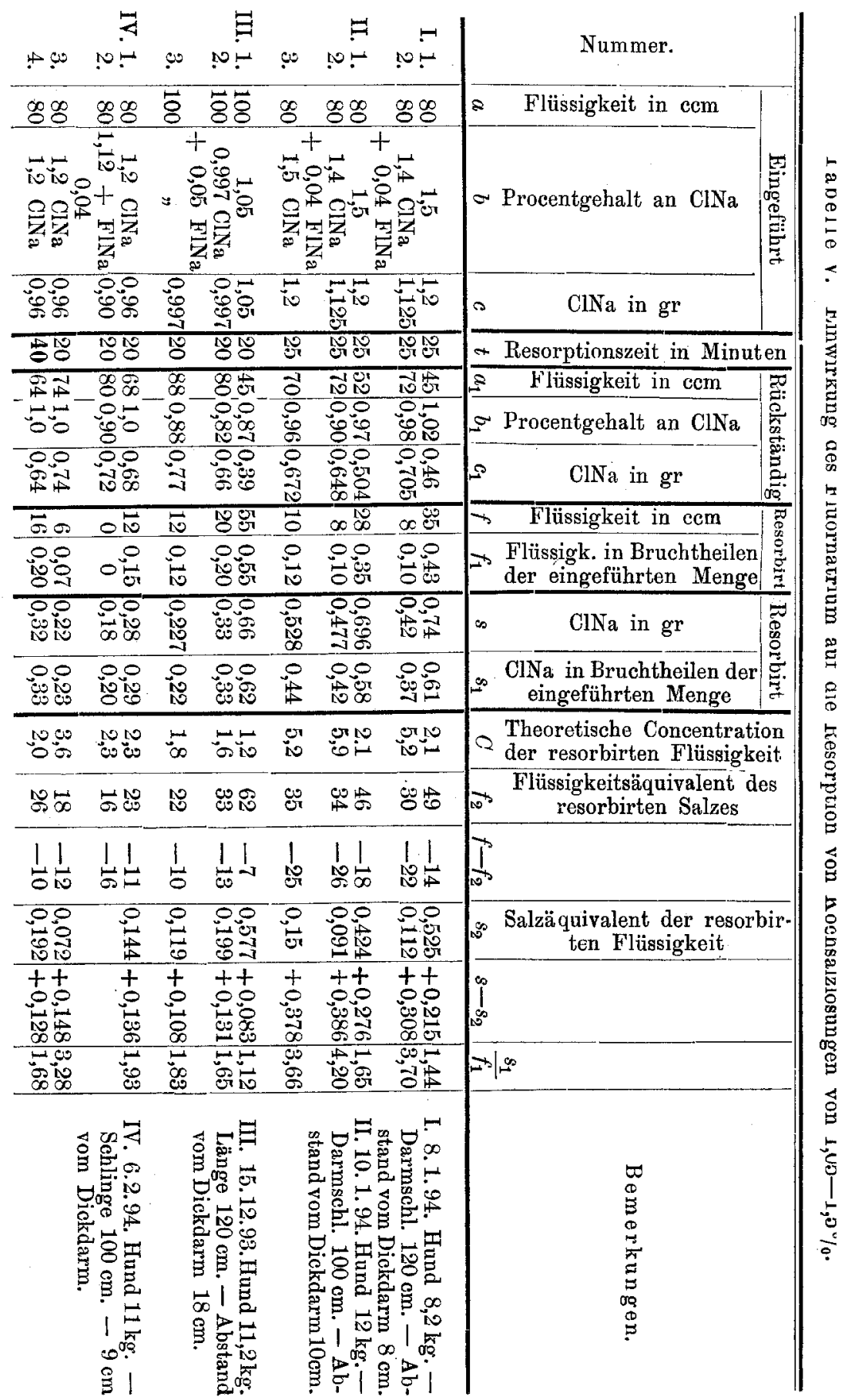


deren Bedeutung die Besprechung der Tabellen III und IV verglichen werden mag; eine Wiederholung würde bei der Einfachheit der Berechnung ïberflüssig sein.

Eine besondre Aufmerksamkeit bitte ich dem Versuche IV der Tabelle $\mathrm{V}$ zu widmen. Der Fluornatriumzusatz zu der 1,2\%igen Salzlösung hat die Folge, dass zunächst die Flüssigkeitsresorption yanz aufhört (IV, 2), während die Salzresorption in geschwächtem Masse fortdanert. Letztere kann hier also nur durch Diffusion zu Stande kommen. Nach Entfernung der Fluormischung und Ersatz durch reine Kochsalzlösung erholt sich allmählich die physiologische Triebkraft (IV, 3), doch wird anch jetzt noch erst in $40^{\prime}$ erreicht (4), was vor der Fluorwirkung in $20^{\circ}$ geleistet wurde. Aus dieser Erholung folgt, dass die Träger dieser Triebkraft durch das Fluornatrium nicht zerstört sind, sondern bei Anwesenheit desselben $(I V, 2)$ nur in ihrer Function beeinträchtigt werden.

Die Uebersicht über die Erscheinungen bei Zusatz von FlNa zu der Darmflitssigkeit zeigt also eine volle Uebereinstimmung des thatsächlichen Verhaltens mit der aus der Theorie abgeleiteten Voraussage $(\S 4, \mathbf{d})$. Dasselbe gilt für die Resorption verdünnter Chlornatriumlösungen, wie die folgende Tabelle (IV) nachweist.

Nach der Theorie (vgl. $§ 4 \mathrm{am}$ Sehlusse) muss das Fluornatrium bei der Resorption der. Lösungen geringer Concentration umgekehrt wirken, wie bei der Aufsaugung höher concentrirter Lösungen: während es bei den letzteren die Wasserresorption stärker herabsetzt als die Salzresorption, muss es bei den ersteren umgekehrt die Salzaufsaugung stärker heruntersetzen, als die Wasseraufsangung. Dass dieses in der That der Fall ist, lehrt die Durchsicht der in der Tab. VI gegebenen Versuchsziffern:

1. Die Werthe der resorbirten Flüssigkeitsmengen $(f)$ sinken nach Zusatz. von FlNa weniger stark, als die Werthe der resorbirten Salzmengen $(s)$. So geht in Versuch I die Flüssigkeitsmenge von 59 auf 33 herab, also noch nicht auf die Hälfte, die Salzmenge dagegen von 0,164 auf 0,025 , also auf weniger als den 7 . Theil ${ }^{1}$ ).

1) Werden die vor der Fluorwirkung resorbirten Wasser $=(f)$ bez. Salzmengen $(s)$ gleich 1 gesetzt, so sind dieselben während der Fluorwirkung

$\begin{array}{ccccc}\text { in Versuch } & \text { I, } 2 & 0,56 & 0,15 \\ \# & \# & \text { II, 2 } & 0,73 & 0,35 \\ " & " & \text { III, 2 } & 0,58 & 0,30\end{array}$

Die relative Abnahme von $f$ und $s$ verhält sich bei den schwachen Concentrationen des ClNa also umgekehrt wie bei den stärkeren. 


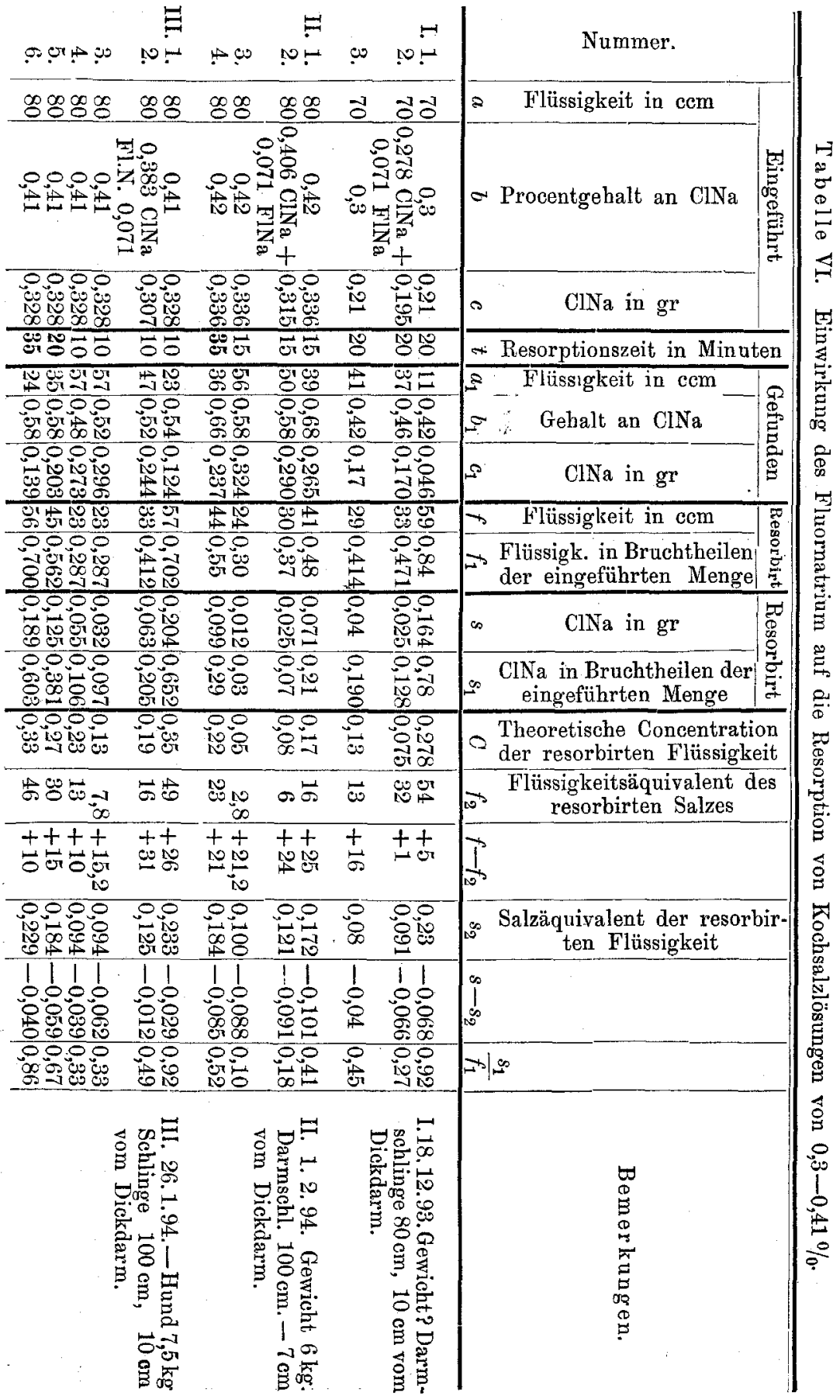


Diese Aenderung der Resorptionsfähigkeit hält lange an. Vergleicht man in Versuch II No. 1 mit No. 4, so zeigt sich, dass nach der Fluornatriumeinwirkung erst in $35^{\prime}$ ungefähr die gleichen Wasserund Salzmengen resorbirt werden, wie vorher in 10 Minuten. A ebnliches lehrt in Versuch III der Vergleich von No. 1 mit No. 5 und No. 6.

2. Die theoretische Concentration der resorbirten Flitssigkeit muss unter diesen Umständen natürlich durch die Fluorwirkung sinken (Col. C) - im Gegensatze zu dem Verhalten bei den stärkeren Salzlösungen.

3. Ebenso sinkt der Werth des Quotienten $\frac{s_{1}}{f_{1}}$, d.h. das Verhältniss der Resorptionsgeschwindigkeit des Salzes zu der des Wassers; der Quotient drückt die durch die Zahlen der Colunnen $f$ und $s$ bezeichneten Thatsachen nur in andrer Form aus. Bei den concentrirteren Lösungen stieg der Werth $\frac{s_{1}}{f_{1}}$ nach derFluorwirkung. Die Gesammtheit also aller Thatsachen, welche über die Wirkung des Fluornatrium, in der geringen Menge von 0,04 bis 0,05\% den Kochsalzlösungen zugesetzt, auf die Gesammtresorption mitgetheilt worden sind, wird durch die bereits oft besprochene Annahme verständlich, dass jene sich aus einem physiologischen und einem osmotisehen Theile zusammensetzt. Indem das Fluornatrium jenen ersteren Theil im Sinne einer Herabminderung beeinflusst, wird es erklärlich, dass es den Resorptionsvorgang der beiden Reihen von Kochsalzlösungen in entgegengesetztem Sinne beeinflusst, bei den höheren Concentrationen stärker die Wasserresorption, bei den geringeren stärker die Salzresorption herabmindernd, weil dort die Wasserresorption, hier die Salzresorption ausschliesslich durch die physiologische Triebkraft zu Stande kommt. Eine physikalische Deutung dieses Verhaltens ist vollständig ausgeschlossen.

Wer etwa die Wirkung des Zusatzes des Fluornatriums nur in der Steigerung der endosmotisehen Spannung der Darmflüssigkeit suchen sollte, obschon diese bei der Geringfügigkeit des $\mathrm{Zu}$ satzes wegen nur minimal sein kann, wird seine Widerlegung in Versuchen der folgenden Art finden. Die endosmotische Gesammtspannung der Kochsalzlösung kann durcb Zusatz eines indifferenten Neutralsalzes erhöht werden, während die Spannung des Kochsalzes 
selbst, gleichen Gehalt der Flüssigkeit an demselben vorausgesetzt, unverändert bleibt. Die Wirkung eines solchen Zusatzes, z. B. von Natriumsulphat, lässt sich nach unsern Principien voraussagen, wenn man im Auge behält, dass die Gesammtresorption sich aus einem physiologisehen und einem physikalischen Antheile zusammensetzt.

Für Kochsalzlösungen geringerer Concentration, deren Spannung niedriger ist, als die der Blutflüssigkeit, wird durch Osmose Wasser $\left(w^{1}\right)$ und durch die physikalische Triebkraft Salzlösung $(w+s)$ in der dargebotenen Concentration fortgefuhrt. Wird nun schwefelsaures Natrium zugesetzt, so steigt die Gesammtspannung der in den Darm eingefuhrten Kochsalzlösung. Die osmotische Triebkraft (gleich der Spannung des Blutes, weniger der Spannung des Darminhaltes) wird also berabgesetzt, die Grösse $w$ wird mithin sinken. Die physiologische Triebkraft wird durch schwefelsaures Natrium ebenfalls herabgesetzt, je nach der Concentration desselben mehr oder weniger, wofür der Beweis im folgenden Paragraphen gegeben wird.

Bei mässigen Concentrationen von schwefelsaurem Natrium leidet die physiologische Triebkraft nur in geringem Grade. Mitbin wird die Wirkung einer geringen Menge von schwefelsaurem Natrium auf die Gesammtresorption von Kochsalzlösungen geringer Concentration darin bestehen miissen, dass die Wasserresorption stark, die Salzresorption nur wenig sinkt. Diese Folgerung bestätigt sich in der Erfahrung vollständig.

Versuch XVII 12. 1. 94.

In einer Darmschlinge von $100 \mathrm{~cm}$ werden resorbirt in je 10 Minuten

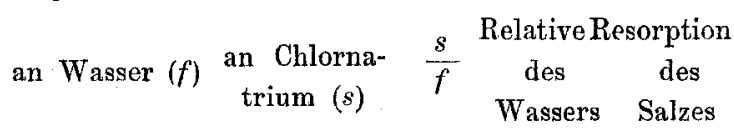

1) Von $80 \mathrm{ccm}$ einer Koch-

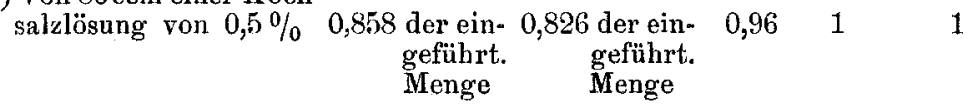

2) Von $80 \mathrm{ccm}$ einer Kochsalzlösung, der noch $2,3 \% \quad \mathrm{SO}_{4} \mathrm{Na}_{2}+10 \mathrm{aq}$. zugesetzt sind 0,250

0,700

$2,40 \quad 0,29$

0,84

3) Von der $0,5 \%$ Kochsalzlösung ohne Zusatz 0,862

0,812

$0,94 \quad 1,00$ 
Versueh XVIII 22. 1. 94.

Von einer Darmschlinge von $100 \mathrm{~cm}$ werden resorbirt

$$
\text { an Wasser }(f) \begin{array}{cccc}
\text { an Chlorna- } & s & \multicolumn{2}{c}{\text { Relative Resorption }} \\
\text { trium }(s) & f & \text { des } & \text { des } \\
\text { Wassers } & \text { Salzes }
\end{array}
$$

1) Von $80 \mathrm{ccm}$ Kochsalz-

lösung $0,51 \%$

2) Von 80 ccm Kochsalz- der ein- $0,80 \quad 1$

geführt.

Menge

lösung $+2,15 \%{ }_{0} \mathrm{SO}_{4} \mathrm{Na}_{2}$

+10 aq. 0,13

der ein- 0,42

Menge

1

1

) Von $80 \mathrm{ccm}$ Kochsalz-

lösung $0,51 \quad 0,63$

4) Von 80 ccm Kochsalz-

lösung $+2,25 \% \mathrm{SO}_{4} \mathrm{Na}_{2}$

+10 aq.

0,15

\begin{tabular}{|c|c|c|c|}
\hline 0,35 & 2,69 & 0,25 & 0,83 \\
\hline 0,56 & 0,88 & 1,21 & 1,33 \\
\hline 0,35 & 3,33 & 0,28 & 0,83 \\
\hline
\end{tabular}

Die Erhöhung der endosmotischen Spannung dünner Kochsalzlösungen durch Zusatz von Natriumsulphat hat also ganz andere Wirkungen, als der Zusatz geringer Mengen von Fluornatrium : dort sinkt die Wasserresorption sehr viel schneller als die Salzresorption, hier ist das Umgekehrte der Fall. Dort ist der Einfluss der Hauptsache nach rein physikalisch; hier kann er nur in einer specifischen Einwirkung des Fluornatrium auf den resorbirenden Apparat seine Erklärung finden. Diese specifische Einwirkung hat anch nach der Entfernung der Fluornatriumbaltigen Flüssigkeit aus dem Darme eine lange Nachwirkung; die Wirknng des Zusatzes von Natriumsulphat ist sofort. nach dessen Entfernung voriiber, vorausgesetzt, dass man den Darm durch Ausspülen griindlich von dem schwefelsauren Salze befreit hat.

Entsprechende Versuche mit Kochsalzlösungen hoher Concentration, deren Spannung bereits erheblich ïber der Spannung der Blutfliussigkeit liegt, lassen sich nicht wohl anstellen, da daun die osmotische Triebkraft, welche einen Wasserstrom aus dem Blute zum Darminhalt herzustellen trachtet, für die entgegengesetzt gerichtete physiologische Triebkraft unüberwindlich wird.

Ich kann diesen Absehnitt nicht schliessen, ohne daranf hinzuweisen, dass bei etwaigen Wiederholungen meiner Versuche die genaue Befolgung der Bedingungen derselben erforderlich ist, wenn 
man zu dem gleichen Resultate kommen will. Namentlich sind dieselben Theile des Dünndarmes zn benutzen. Denn ich babe gesehen, dass der obere Theil des Dünndarmes sich, wenn auch nicht qualitativ, so doch quantitativ etwas anders verbält, als der untere:

Als ich bei einem Hunde in eine $100 \mathrm{~cm}$ lange Schlinge, die in $8 \mathrm{~cm}$ Entfernung vom Dickdarm begann, $80 \mathrm{ccm}$ Kochsalzlösung von $1,5 \%$ fällte, waren nach $25^{\prime}$ resorbirt $35 \mathrm{ccm}$ Flüssigkeit ( $=0,43$ der ursprünglichen Menge) und 0,74 grm Kochsalz $=0,61$ der eingeführten Menge. - Bei Einfällung von $75 \mathrm{ccm}$ derselben Kochsalzlösung, denen $5 \mathrm{ccm}$ einer einprozentigen Lösung von Fluornatrium zugesetzt wurden, sank die Flüssigkeitsresorption auf $8 \mathrm{ccm} \quad(=0,12$ der eingeführten Menge $)$, die Salzresorption auf 0,420 grm $=0,37$ der eingeführten Menge.

Eine gleich lange Schlinge, die in $60 \mathrm{~cm}$ Entfernung vom Pylorus begann, resorbirte unter gleichen Umständen von $80 \mathrm{~cm}$ Kochsalzlösung von $1,5 \%$ nur $10 \mathrm{~cm}$; als sie mit $75 \mathrm{cem}$ der gleichen Salzlösung nnd $5 \mathrm{ccm}$ FlNa von $1 \%$ beschickt wurde, trat in $25^{\prime}$ keine Resorption mehr ein, sondern das Flüssigkeitsvolumen vergrösserte sich in $25^{\prime}$ um $5 \mathrm{ccm}$.

Eine Wiederholung dieses Versuches an einem zweiten Hunde gab ähnliche Resultate.

Es scheint demnach, dass die physiologische Resorptionskraft 1. im oberen Darmtheile geringer ist, als im unteren, denn dort wurden aus der $1,5 \%$ Kochsalzlösung in derselben Zeit nur $10 \mathrm{ccm}$ Flüssigkeit entfernt, in welcher hier $35 \mathrm{ccm}$ verschwanden; 2 . dass jene Kraft im obern Darmtheile durch das FlNa in höherem Massé geschädigt wird, als im untern, denn dort wurde sie nach dem $\mathrm{Zu}$ satze desselben durch die entgegengesetzt gerichtete osmotische Triebkraft ïberwunden, welche in der Spannungsdifferenz zwischen Blut $(A=0,64 a)$ und Darminbalt $(A=0,926)$ gegeben ist, hier blieb sie der Osmose Herr, denn es wurde noch etwas Fltissigkeit resorbirt.

\section{S 6. Resorption oiniger anderer Salze.}

Nachdem die Resorption der Chlornatrium-Lösungen eine eingehende Unteruchung gefunden, lag es nahe, andere Salze in derselben Weise zu prïfen. Aber bätte ich ähnlich ausgedehnte Ver- 
suchsreihen, wie sie oben bezüglich des Kochsalzes mitgetheilt sind, auf eine grössere Zahl von Salzen ausdehnen wollen, so hätte ich die Veröffentlichung meiner bisherigen Ergebnisse, die zu erlangen eine nicht geringe Arbeit kostete, noch auf Jahre hinausschieben müssen. Ich lasse es daher bei der Mitheilung einiger bisheriger Resultate bewenden, welche mir principiell wichtig erscheinen.

Würde die Wasserresorption nur durch die endosmotische Spannung des Darminhaltes und das Verhältniss derselben zu der des Blutes bestimmt, so müsste aus isotonischen Lösungen verschiedener Salze bei der Darmresorption das Wasser mit gleicher Gesehwindigkeit aufgesogen werden, was nicht entfernt der Fall ist. Die Resorption des Wassers aus Chlornatrium-Lösungen z. B. erfolgt anch dann noch viel schneller, als aus Bittersalzlösungen, wenn letztere eine erheblich geringere Spannung besitzen, als erstere.

In einem Versuche verglich ich die Resorption einer Kochsalzlösung von $1 \%(A=0,640)$ mit einer Lösung von schwefelsaurer Magnesia $\left(\mathrm{So}_{4} \mathrm{Mg}+7 \mathrm{H}_{2} \mathrm{O}\right.$ von $\left.5,85 \%{ }^{1}\right)(A=0,516)$, indem ich in eine Darmschlinge abwechselnd $80 \mathrm{ccm}$ beider Lösungen füllte und die Resorption je 25 Min. dauern liess.

Es wurden resorbirt

1. von der Kochsalzlösung $45 \mathrm{cem}=56 \quad \%$

2. von der schw. Magnesialösung $5 \mathrm{ccm}=6 \quad$,

3. von der Kochsalzlösung $44 \mathrm{ccm}=55$,

4. von der Lösung von schw. Magnesia $6 \mathrm{cem}=7,5$ "

5. von der Kochsalzlösung

$40 \mathrm{ccm}=0,50$,

Nehme ich für beide Lösungen die Mittelzahlen, so wird das Wasser aus der Kochsalzlösung trotz ihrer höheren Spannung (die Differenz der $\Delta$ beträgt $\left.0,124^{\circ}\right) 8,13 \mathrm{mal}$ so schnell aufgesogen, als aus der Bittersalzlösung. Das Serum des Hundes hatte $\Delta=0,624$.

In einem anderen Versuche wurde unter ubrigens ganz gleichen Verhältnissen die einprocentige Kochsalzlösung mit Bittersalzlösungen von $4,5 \%(\Delta=0,464)$ und von $3,37 \% \quad(\Delta=0,338)$ verglichen. Es wurden in $25^{\prime}$ resorbirt von $80 \mathrm{ccm}$

1. der $1 \%$ Kochsalzlösung $72 \mathrm{ccm}=90 \%$

2. " 4,5\% Bittersalzlösung $21,=26$ "

1) Nach den von de.Vries gegebenen Zahlen ist eine einprocentige Kochsalzlösung isotonisch mit einer $6,3 \%$ Lösung von schwefels. Magnesia. 


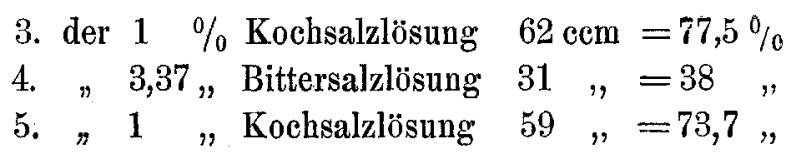

Das Serum des Hundes hatte $\Delta=0,632$.

Einen dritten Versuch will ich ausführlich mittheilen, weil ich in demselben nahezu diejenige Concentration der schwefelsauren Magnesia traf, aus welcher das Wasser so schnell resorbirt wird, wie aus einer einprocentigen Kochsalzlösung. In diesem Versuche sind ansser den resorbirten Wassermengen auch die resorbirten Salzmengen quantitativ bestimmt.

\section{Versuch XIX 27. 2. 94.}

Hund 7 Kilo. Darmschlinge $100 \mathrm{~cm}, 9 \mathrm{~cm}$ vom Dickdarm.

I. gh $^{\prime}$ eingeführt $80 \mathrm{ccm}$ ClNa $1 \%=0,8 \mathrm{gr}$

in $\frac{33^{\prime} \text { gefunden } 23 " n \quad 0,880=0,202 "}{25^{\prime} \text { resorbirt } 57 \mathrm{ccm}} \quad 0,701 \quad 0,747 \quad 1,06$

II. $9 \mathrm{~h} 40^{\prime}$ eingef. $50 \mathrm{ccm}$ schw. Magn. $1,63 \%=1,304 \mathrm{gr}$

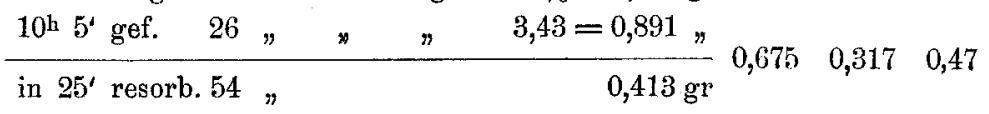

III. $10^{\mathrm{h}} 12^{\prime}$ eingeführt $80 \mathrm{ccm}$ ClNa $1 \%=0,8 \mathrm{gr}$

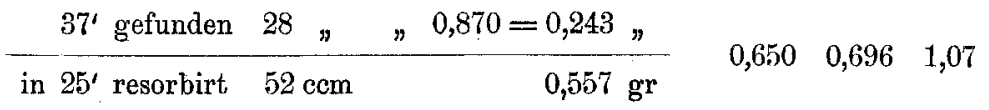

IV. $10^{\mathrm{h}} 41^{\prime}$ eingef. $80 \mathrm{ccm}$ schw. Magn. $1,63 \%=1,304 \mathrm{gr}$

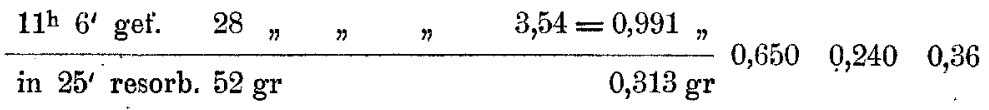

V. $11^{\text {h } 11^{\prime}}$ eingeführt $80 \mathrm{~cm}$ ClNa $1 \%=0,8 \mathrm{gr}$ $\begin{array}{rrrr}36^{\prime} \text { gefunden } 34 " n & 0,890=0,302 " & 0,425 & 0,622 \quad 1,46\end{array}$

$$
\begin{array}{r}
\Delta \mathrm{ClNa} 1 \%=0,640 \\
\mathrm{SO}_{4} \mathrm{Mg}+7 \mathrm{H}_{2} \mathrm{O} 1,63 \%=0,226 \\
\text { Serum }=0,632
\end{array}
$$

Die osmotische Triebkraft entspricht

für die Kochsalzlösung $\quad A=0,632-0,640=-0,008^{1}$ )

\# Bittersalzlösung $A=0,632-0,226=+0,406$

1) D. h. der Resorption des Wassers wirkt eine Triebkraft von obigem Betrag entgegen. 
Bei der Resorption der Kochsalzlösung wirkt eine allerdings geringe Triebkraft von $\Delta=0,008$ der Aufsaugung des Wassers entgegen, denn das $\Delta$ ist für die Kochsalzlösung um jenen Werth grösser als für das Blut; trotzdem wird die einprocentige Kochsalzlösung eben so schnell resorbirt, als die $1,6 \%$ Bittersalzlösung obschon bei dieser eine osmotische Triebkraft von $\triangle 164-216=0,406$ (entsprechend einem Drucke von etwa 3,5 Meter Quecksilber) im Sinne der Wasserresorption wirkt.

Diese Thatsache ist unverständlich, so lange man die Resorption durch einfache physikalische Diffusion zu Stande kommen lassen will.

Man pflegte früherhin bei Besprechung der Resorption verschiedener Salze auf die Verschiedenheit ihres endosmotischen Aequivalentes als Ursache ihres verschiedenen Verhaltens aufmerksam zu machen. Bei der Resorption von Bittersalz müsse mehr Wasser in den Darm übertreten, als bei der Resorption von Kochsalz, weil das Aequivalent des ersteren etwa 6 mal so hoch sei, als des letzteren, daher auch die laxirende Wirkung der Sulphate. Aber die absoluten Mengen von Salz, welche bei den obigen Versuchen zur Resorption gelangen, bemessen sich nur nach Decigrammen, die dafür ausgetauschten Wassermengen sind also jedenfalls so gering, dass sie gegenüber den grossen resorbirten Wassermengen gar nicht in Betracht kommen.

Die rein physikalischen Verhältnisse der verschiedenen Salze geben also keine Erklärung für die Verschiedenheit ihrer Einwirkung auf die Wasserresorption im Darm. So weit ich sehe, wird die stark verzögernde Wirkung, welche das Bittersalz auf die Aufsaugung ausiibt, nur durch die Annahme zu deuten sein, dass die Gegenwart desselben die physiologisehe Resorptionskraft der Darmwand in hohem Masse beeinträchtigt.

\section{Schlussbemerkungen.}

Der Leser, welcher meinen Auseinandersetzungen gefolgt ist, hat mit mir ein steriles Stück Arbeit durchgemacht; denn die Durchsicht langer Zahlentabellen, ohne welche meine Untersuchungen nicht verständlich sind, ist so trocken und langweilig, wie ihre Herstellung. Ich hoffe aber, bei denjenigen, welche diese Mühe nicht scheuten, die Ueberzengung erweckt zu haben, von der ich 
selbst durchdrungen bin, dass bei der Darmresorption stets eine der Darmwand selbst entstammende Triebkraft thätig ist, welche unter bestimmten Bedingungen allein, unter bestimmten andern in Combination mit osmotisehen Triebkräften wirksam wird. Die Gründe für diese Auffassung sind so breit und so wiederholt besprochen worden, das ich mir ibre nochmalige Wiederbolung fiiglich ersparen kann.

Die Verquickung einfach physikalischer und physiologischer Triebkräfte ist gewiss überaus bäufig. In meinen Untersuchungen iiber die Bildung der Lymphe habe ich z. B. nachgewiesen, dass Erscheinungen der Filtration und der Diffusion dabei auftreten können, dass aber andererseits jene physikalischen Processe allein gewisse, die Entstehung der Lymphe betreffende Thatsachen zu erklären nicht im Stande sind. Leider ist es mir bisher nicht möglich gewesen, die physikalischen und physiologisehen Triebkräfte bier in dem Masse auseinander zu wirren, wie es für die Darmresorption gelungen ist. Die jetzt vorliegenden Erfahrungen uiber die Resorption werden, so hoffe ich, künftighin bei Beurtheilung ähnlicher Vorgänge zu grösserer Vorsicht auffordern, als sie bisher geiibt worden ist ${ }^{1}$ ).

Absichtlich habe ich mich bisher über die physiologische Triebkraft nicht ansgesprochen. Von welchem Theile der Darmwand geht sie ans? Worauf beruht sie? - Fragen, die sich von selbst stellen, aber schwer beantworten lassen.

Dass der Träger jener Triebkraft das Epithel sei, wird wohl kaum bezweifelt werden; schon Hoppe-Seyler hat daranf

1) Hier und da wird mir die Ansicht untergeschoben, die Lymphbildung sei n a r ein durch die Capillarzellen vermittelter Secretionsprocess. Ich habe aber nur behauptet, dass Secretionskräfte mitwirken. Auf S. 68 meiner Abhandlung steht: „bei der Lymphbildung kommen noch andere Vorgänge in Betracht, als die mechanische Durchpressung von Flüssigkeiten durch durchlässige Membranen“. Ferner S. 69: "Es gehört zu "den unbefriedigenden Punkten meiner Untersuchung, dass ich nicht in der "Lage bin, die Grenze zwischen mechanischer Filtration und Secretion scharf „zu bezeichnen. Unmöglich wäre es nicht, dass es eine scharfe Grenze . . . "überhaupt nicht gäbe, dass vielmehr oft beide gleichzeitig stattfinden". Die Filtration ist also als Factor bei der Lymphbildung im allgemeinen nicht geleugnet, aber ihr als zweiter Factor die Thätigkeit der Capillarzellen an die Seite gestellt. 
aufmerksam gemacht, dass nach Zerstörung desselben die Resorption aufhört.

Das Epithel setzt sich aus Zellen und aus Kittsubstanz zusammen. Beide sind Resorptionswege, denn es hat sich gezeigt, dass bei Resorption von Farbstofflösungen der Farbstoff sowohl in den Zellen, als in der Kittsubstanz nachweisbar ist ${ }^{1}$ ). Was auf letzterem Wege aus dem Darm in die Schleimbaut übertritt, wird aller Wahrscheinlichkeit nach durch Diffusion befördert ${ }^{2}$ ). Die active Rolle wird den Epithelzellen selbst zukommen müssen. $S p$ in $a^{3}$ ) glaubt sich an dem Darm von Insectenlarven überzeugt zu haben, dass die Epithelzellen, indem sie sich von ihrer freien Kuppe an bis zum Fussende vergrössern, Flitssigkeit aus dem Darme aufsaugen, die aufgenommene Flüssigkeit aber weiter treiben, indem sie sich von der Kuppe nach dem Fussende hin allmählig wieder verkleinern. Jede Zelle würde also als eine kleine Saugund Druckpumpe fungiren. Sollten sich diese Angaben bestätigen,Nachuntersuchungen sind mir nicht bekannt ${ }^{4}$ ) - so würde damit die Rolle der Epithelzellen doch sicherlich nicht erschöpft sein. Es ist aber besser, statt sich auf Vermuthungen einzulassen, die ja sehr weit ausgesponnen werden könnten, offen zu gestehen, dass wir vorläufig auf das Verständniss der Resorptionsleistung der Zellen ebenso verzichten müssen, wie auf eine nähere Einsicht in die Absonderungsleistungen der Drüsenzellen.

1) Vgl. R. Heidenhain, Beiträge zur Histologie und Physiologie der Dünndarmschleimhaut. Bonn 1888. S 49. (Supplementband zu Pflüger's Archiv.)

2) Vgl. Arnold, Die Kittsubstanz der Epithelien. Vir chow's Archiv Bd. 64 .

Thoma, Die Kittsubstanz der Epithelien, Ebendas. S. 394.

A rnold, die Kittsubstanz der Endothelien. Ebendas. Bd. 66.

3) A. Spina, Ueber Resorption und Secretion. Leipzig 1882.

4) Bei der Einwirkung starker Salzlösungen schnürt sich, wie ich in der sub 1 citirten Abhandlung gezeigt habe (S. 15-18), das oberste Stückchen des Protoplasmas der Epithelzellen sammt den Stäbchen ab, so dass freie Gebilde entstehen, die ich "Haarzellen" genannt habe; diese Beobachtung beweist die Contractionsfähigkeit des Protoplasmas. 